\title{
A Late Triassic lake system in East Greenland: facies, depositional cycles and palaeoclimate
}

\author{
Lars B. Clemmensen ${ }^{\mathrm{a}, *}$, Dennis V. Kent ${ }^{\mathrm{b}}$, Farish A. Jenkins, Jr. ${ }^{\mathrm{c}}$ \\ ${ }^{a}$ Geological Institute, University of Copenhagen, DK-1350 Copenhagen K, Denmark \\ ${ }^{b}$ Lamont-Doherty Earth Observatory, Columbia University, Palisades, NY 10964, USA \\ ${ }^{c}$ Department of Organismic and Evolutionary Biology and Museum of Comparative Zoology, Harvard University, \\ Cambridge, MA 02138, USA
}

Received 24 May 1996; accepted 18 January 1997

\begin{abstract}
The Upper Triassic Fleming Fjord Formation of the Jameson Land Basin in East Greenland contains a well-exposed succession, 200-300 m thick, of lake deposits. The Malmros Klint Member, 100-130 m thick, is composed of cyclically bedded intraformational conglomerates, red siltstones and fine-grained sandstones and disrupted dolomitic sediments (paleosols). The cyclicity is composite with cycles having mean thicknesses of (25), 5.9 and $1.6 \mathrm{~m}$. The overlying Carlsberg Fjord beds of the Ørsted Dal Member, 80-115 m thick, are composed of structureless red mudstones rhythmically broken by thin greyish siltstones. This unit also has a composite cyclicity with cycles having mean thicknesses of 5.0 and $1.0 \mathrm{~m}$. The uppermost Tait Bjerg Beds of the Ørsted Dal Member, 50-65 m thick, can be divided into two units. A lower unit is composed of cyclically bedded intraformational conglomerates or thin sandstones, red mudstones, greenish mudstones and yellowish marlstones. An upper unit is composed of relatively simple cycles of grey mudstones and yellowish marlstones. Recognized cycles have mean thicknesses of 5.6 and $1.6 \mathrm{~m}$. The lake deposits contain evidence of seasonal, orbital and long-term climatic change. Seasonal change is documented by numerous desiccation surfaces especially in the Malmros Klint Member and Carlsberg Fjord beds, orbital change is suggested by the composite cyclicity, and long-term climatic change is indicated by the systematic upwards change in sedimentary characteristics of the lake deposits. The sedimentary features of the Malmros Klint Member suggest lacustrine deposition in a dry climate that fluctuated between desert and steppe conditions, the Carlsberg Fjord beds probably record lacustrine lake deposition in a rather constant dry (steppe) climate, while the Tait Bjerg Beds record lake sedimentation in a climate that fluctuated between dry (steppe) and warm moist temperate. In the Tait Bjerg Beds the upward change in cycle characteristics indicates a shift towards more humid conditions. Climatic deductions from sedimentary facies are in good agreement with climate maps of Laurasia, as simulated by numerical climate models. Palaeomagnetic data indicate a northward drift of East Greenland of about $10^{\circ}$ from ca. $25^{\circ} \mathrm{N}$ to ca. $35^{\circ} \mathrm{N}$ in the Middle to Late Triassic. The Fleming Fjord Formation which represents ca. 5 m.y. of the Late Triassic interval was deposited during latitudinal drift of $1-2^{\circ}$. It is possible that the observed long-term upward shift in climatic indicators within the formation can be ascribed to plate drift, but southward shift of climatic belts could also have been of importance. (c) 1998 Elsevier Science B.V. All rights reserved.
\end{abstract}

Keywords: Late Triassic; East Greenland; lake facies; orbital control; long-term climatic changes; palaeolimnology

\footnotetext{
* Corresponding author. Tel.: +45-35322449; Fax: +45-33148322. 


\section{Introduction}

Late Triassic lake deposits are relatively common in the northern hemisphere and well-known examples include the Keuper deposits of northern Germany (e.g. Aigner and Bachmann, 1992), the Mercia Mudstone Group of England (e.g. Tucker, 1978; Talbot et al., 1994), the Chinle Formation of North America (e.g. Dubiel et al., 1991), and the Newark Supergroup of North America (e.g. Van Houten, 1964; Olsen, 1986; Gierlowski-Kordesch and Rust, 1994).

The tropical lake deposits in the Late Triassic Newark rift basins along the east coast of North America have been studied in much detail in recent years. These lake deposits are strikingly cyclic in nature, and as documented by Olsen (1986) and Olsen and Kent (1996) this cyclicity can be related to orbitally controlled lake level variations.

The Jameson Land Basin in East Greenland contains a well-exposed Late Triassic lake succession (Clemmensen, 1980a, 1980b). In Late Triassic times the Jameson Land Basin was situated at ca. $35^{\circ} \mathrm{N}$ in the interior of Laurasia (Kent and Clemmensen, 1996). Northward drift of the basin during the Triassic has been documented by Kent and Clemmensen (1996). This change in palaeolatitude should influence the palaeoclimatic setting of the basin, and a significant long-term (Middle-Late Triassic) change in depositional environments and palaeoclimate is in fact seen in the basin (e.g. Clemmensen, 1980a, 1980b; Kent and Clemmensen, 1996).

The Late Triassic lake deposits of the Fleming Fjord Formation of East Greenland show pronounced cyclicity (Clemmensen, 1980a; Jenkins et al., 1994). The cyclicity is composite and Jenkins et al. (1994), Clemmensen and Kent (1995) and Kent and Clemmensen (1996) suggest that the cylicity was related to orbital forcing of the climate.

Precise estimates of depositional duration of such Late Triassic lake deposits have until recently been very problematic. Detailed lithostratigraphical, magnetostratigraphical and cyclostratigraphical work in the Newark basin, has however, resulted in a good time scale for the Late Triassic in lacustrine facies (e.g. Kent et al., 1995).

Integrated sedimentological, magnetostratigraphical and cyclostratigraphical work was initiated in the
Jameson Land basin in 1992 in combination with vertebrate palaeontological fieldwork (Clemmensen and Kent, 1995; Kent and Clemmensen, 1996; Jenkins et al., 1994). This work was continued in 1995. The aim of the studies was (1) to document the lacustrine and associated facies in the Late Triassic lake system and to reconstruct lake environments and processes, (2) to describe the sedimentary cycles in relation to lake-level variations and climatic change, and (3) to explain the long-term evolution of the lake system in relation to palaeolatitudes, palaeoclimatic belts and plate drift. Emphasis is here given to a description of facies and depositional cycles from the middle part of the Fleming Fjord Formation.

\section{Palaeoclimatic setting}

In Late Triassic times the Jameson Land Basin was situated at ca. $35^{\circ} \mathrm{N}$ in the central part of Laurasia (Kent and Clemmensen, 1996). Climate model experiments by Kutzbach (1994) suggest that the normal ('control') climate of the Jameson Land Basin region in the Late Triassic was relatively dry with precipitation being less than $2 \mathrm{~mm} /$ day $(700 \mathrm{~mm} / \mathrm{yr})$ and fairly evenly spread over the year. Temperatures varied between ca. $10^{\circ} \mathrm{C}$ in the winters and ca. $45^{\circ} \mathrm{C}$ in the summers. The soil moisture was low during the hot summer months, but reached $40 \mathrm{~mm}$ in the winter (Kutzbach, 1994). According to this model results the basin was lying outside monsoonal influence at the margin of the dry interior of Laurasia.

The model experiments of Kutzbach (1994) also describe climatic conditions during climatic extremes related to orbital change. During periods of summer perihelion in the northern hemisphere (increased seasonality), monsoonal circulation was intensified and it is possible that the Jameson Land Basin was just within the reach of the monsoons. Model experiments indicate a $25 \%$ increase in summer precipitation during these climatic conditions (Kutzbach, 1994). Periods of maximum seasonality were also characterized by increased winter precipitation in connection with westerly winds. These precession-forced changes should be large enough to significantly alter the pattern of vegetation, drainage and sedimentation in the Jameson Land Basin (cf. Kutzbach, 1994). 
The above idealized reconstruction of Pangaean climates does not take local conditions into account. The Jameson Land Basin was situated relatively close to the Boreal Sea; winds blowing from this seaway may have brought additional moisture into the basin. Local orographic features, such as the western mountain range bordering the basin, may also have contributed to an increase in the precipitation rate over the area. In addition sea level may have controlled the overall climatic setting of the basin, whereby monsoonal activity was probably shifted northward during periods of sea level highstands (and vice versa), in agreement with the ideas of Zwan and Spaak (1992).

On a long-term time scale the palaeoclimatic setting of the Jameson Land Basin was probably influenced by several parameters including plate drift and long-term sea level change. Palaeomagnetic studies by Kent and Clemmensen (1996) indicate a northward drift of the basin from Middle to Late Triassic times of ca. $10^{\circ}$. The Fleming Fjord Formation, which represents ca. 5 m.y. of the Late Triassic, was deposited during latitudinal drift of $1-2^{\circ}$.

From the above theoretical considerations, we hypothesize that the Jameson Land Basin lay in an area that allowed significant yearly as well as orbitally induced climatic changes to take place. The basin would have received most precipitation during periods of enhanced seasonality. As variations in precipitation related to orbital change ranged up to $\pm 25 \%$ (cf. Kutzbach, 1994), we suspect that these variations in precipitation and related runoff would leave a clear signal in the sedimentary record.

A long-term slow northward drift of the basin would change the climatic setting from overall dry to warm, moist temperate (Köppen climate classification, Koeppe and De Long, 1958). A northward drift of the basin would decrease the likelihood of monsoonal influence, but increase the influence of westerly air flow. The long-term sea level fall in the Late Triassic (e.g. Haq et al., 1988) could also shift monsoonal activity southward with time (cf. Zwan and Spaak, 1992). We suspect that these long-term changes in palaeoclimatic setting also are recorded in the sediments of the Fleming Fjord Formation.

\section{Geological setting}

The Jameson Land Basin is situated at the southern end of the East Greenland rift system (Fig. 1). It is bounded to the west by a major $\mathrm{N}-\mathrm{S}$-trending fault, to the east by the Liverpool Land area, and to the north by a fault system in the Kong Oscar Fjord region (Clemmensen, 1980a; Surlyk, 1990). The subsidence of the Triassic Jameson Land Basin was mainly related to thermal contraction (Surlyk et al., 1986). Several Triassic phases of fault-controlled subsidence, however, have been documented (Clemmensen, 1980a; Surlyk et al., 1981).

The Jameson Land Basin contains a relatively thick succession of Lower Triassic to Lower Jurassic continental sediments (Pingo Dal, Gipsdalen, Fleming Fjord and Kap Stewart formations) including alluvial fan, braided river, aeolian desert, flood plain, saline playa lake and freshwater lake deposits (Clemmensen, 1980a; Dam and Surlyk, 1993). The Fleming Fjord Formation, which forms a spectacular variegated to claret-coloured unit in the exposures of the Triassic continental succession, is predominantly of lacustrine origin. The lake deposits are well exposed especially in the eastern part of the basin. Present outcrops of the lacustrine facies in the Fleming Fjord Formation suggest that the lake had an area of ca. $3000 \mathrm{~km}^{2}$ (Fig. 1). The size of the lake fluctuated much in relation to climatic change.

The basin was relatively close to the Boreal Sea and the sea invaded the basin at least once during deposition of the Triassic continental succession (cf. Clemmensen, 1980a, 1980b). Published sea level curves for the Triassic (e.g. Haq et al., 1988) show a long-term sea level highstand in the early Norian and gradually falling sea level in the remaining part of the Triassic. Short-term sea level highstands occur in the late Carnian, mid-Norian and the late Rhaetian.

\section{Stratigraphy}

The Upper Triassic Fleming Fjord Formation is composed of a basal Edderfugledal Member, a middle Malmros Klint Member and an uppermost Ørsted Dal Member (Fig. 2; Clemmensen, 1980b).

The sedimentology of the predominantly lacustrine Edderfugledal Member, 30 to 70 m thick, was 


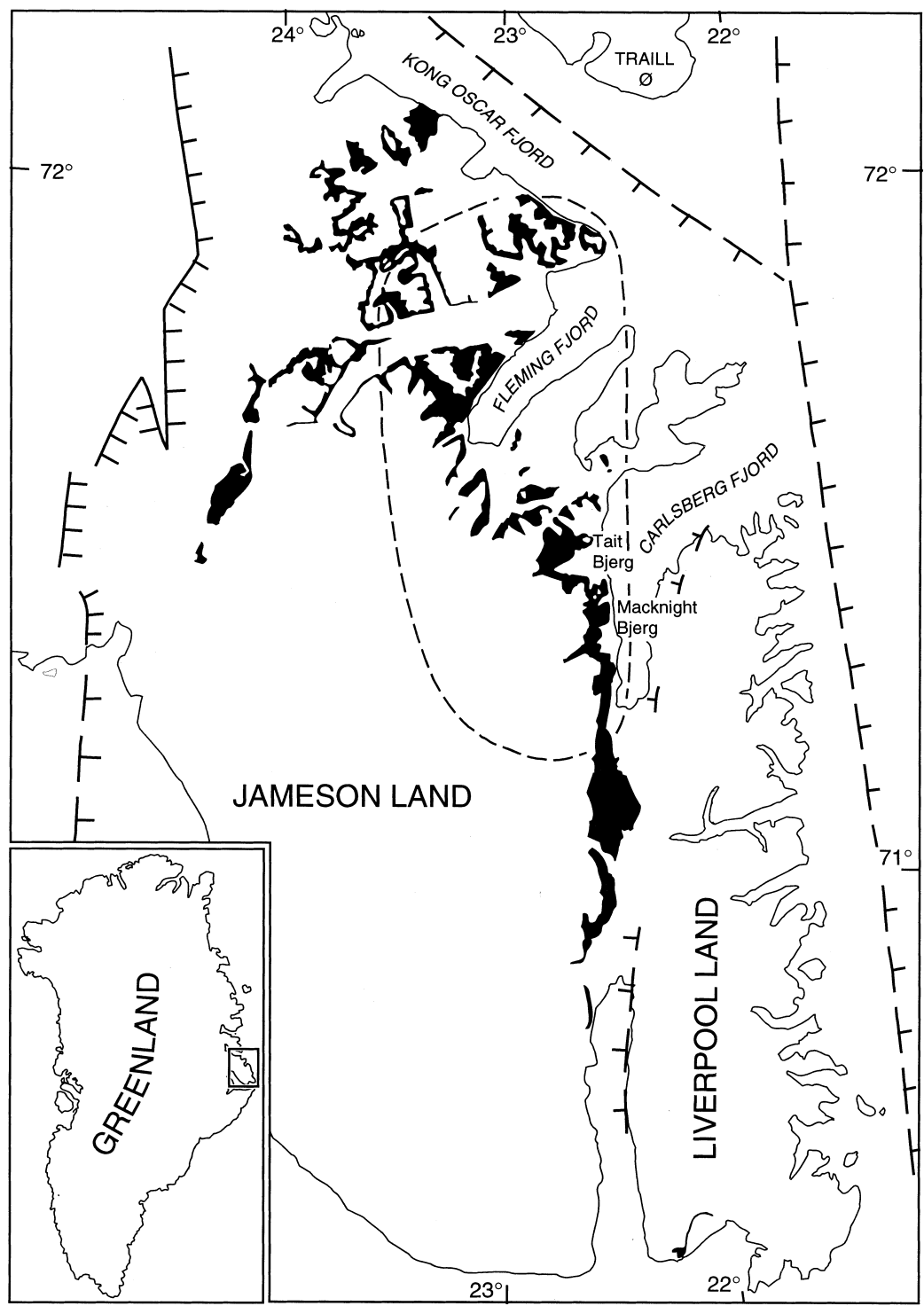

Fig. 1. The Jameson Land Basin in East Greenland. Outcrops of the Upper Triassic Fleming Fjord Formation are indicated in black and the presumed depocenter of the lake is outlined by the discontinuous line. The localities studied in most detail during the fieldwork are the Tait Bjerg section and the Macknight Bjerg section in the eastern part of the depositional basin. Source: maps from GEVS.

described by Clemmensen (1978). Apparently the Edderfugledal Member was deposited in a shallow fresh to slightly saline lake subject to rare marine transgressions. We have collected only few new data from this member and will not discuss the sedimentology and palaeoclimatic aspects of the member here.

The Malmros Klint Member forms a very conspicuous Late Triassic lake unit, and the member forms al- most vertical 100-130 $\mathrm{m}$ high cliffs in the eastern part of the basin. The member can be divided into a lower sandstone-rich unit and an upper claystone-rich unit (Jenkins et al., 1994). The sandstone-rich and cliffforming part of the member thins drastically towards the west; the thinning is partly compensated by an increase in the thickness of the overlying claystone-rich unit. Early observations of the sedimentology of this 


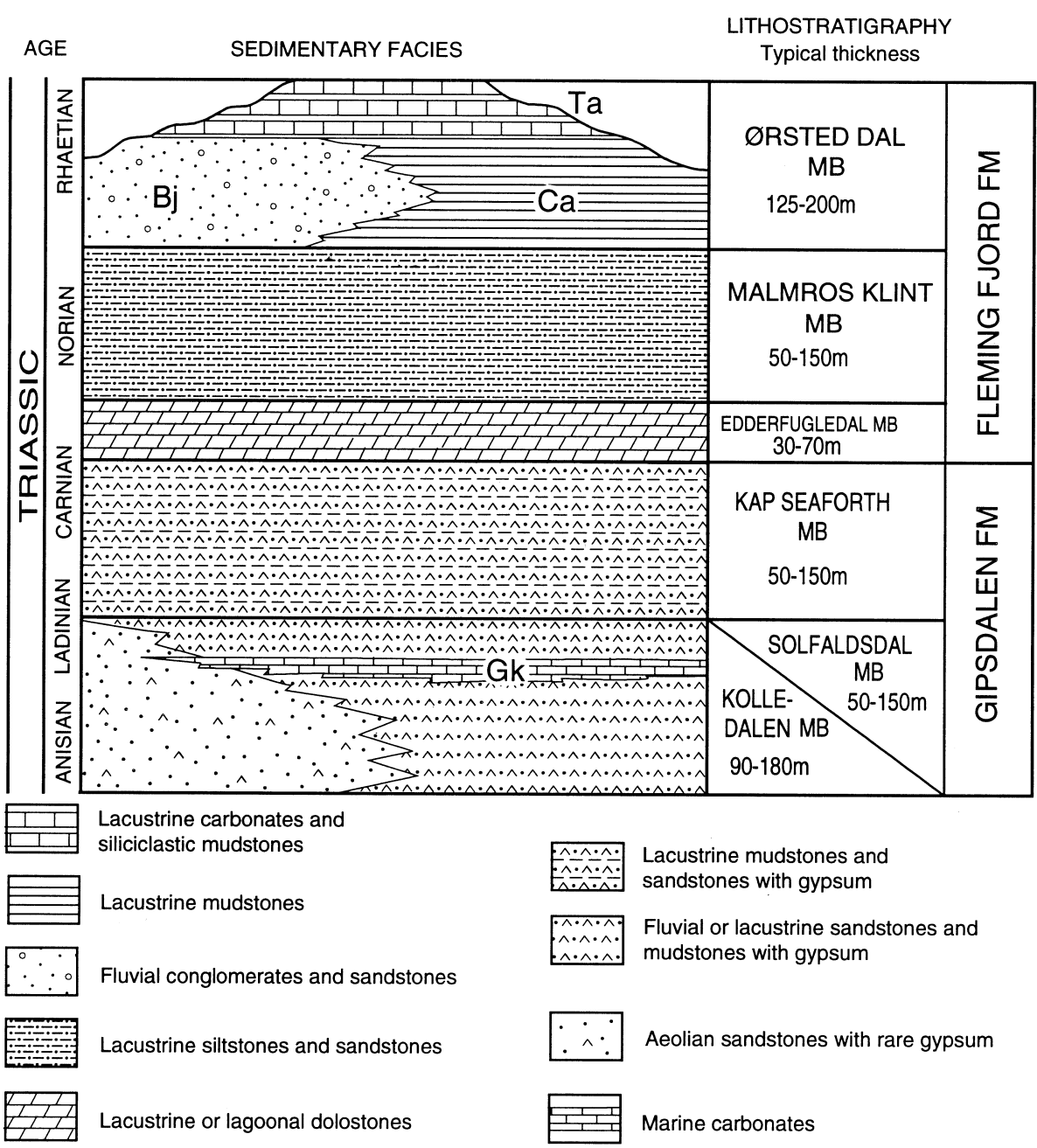

Fig. 2. Simplified stratigraphic scheme for Middle and Upper Triassic rock units in Jameson Land Basin, East Greenland (from Kent and Clemmensen, 1996). $C a=$ Carlsberg Fjord beds; $B j=$ Bjergkronerne beds; $T a=$ Tait Bjerg Beds.

member were summarized by Clemmensen (1979). Recent studies, however, have added new information on the sedimentology and depositional conditions of this member. These data form the basis of the following description of facies and depositional cycles.

The Ørsted Dal Member has a more complex internal stratigraphy than the Malmros Klint Member (Fig. 2). Towards the east at Carlsberg Fjord the member is composed of a basal unit of clay-rich lacustrine mudstones and thin siltstones. This unit is $85-115 \mathrm{~m}$ thick and was termed the Carlsberg Fjord beds by Jenkins et al. (1994). Overlying the Carlsberg Fjord beds with a gradual contact are the
Tait Bjerg Beds composed of lacustrine deposits of siliciclastic mudstones and impure limestones and dolostones (marlstones) (Clemmensen, 1980b; Jenkins et al., 1994). In the central and western part of the basin the basal Carlsberg Fjord beds are replaced by fluvial mudstones, sandstones and conglomerates of the Bjergkronerne beds (Jenkins et al., 1994). The fluvial deposits reach a thickness of almost $200 \mathrm{~m}$ and are overlain by a thin unit of carbonates and associated deposits of the Tait Bjerg Beds (Clemmensen, 1980b; Jenkins et al., 1994).

The Fleming Fjord Formation is overlain by the fluvial and lacustrine Kap Stewart Formation (Dam 
and Surlyk, 1993). The boundary between the two formations is developed as an unconformity in the basin margins. Basinwards the unconformity passes into a correlative conformity (Dam and Surlyk, 1993).

Based on samples collected in the 1992 field season Kent and Clemmensen (1996) present a preliminary magnetostratigraphy of the Malmros Klint and lowermost Ørsted Dal members in the Carlsberg Fjord area. Seven polarity intervals are delineated in the $210 \mathrm{~m}$ thick sampled section. A normal-reversed-normal polarity magnetozone sequence occurs in the lower part of the Malmros Klint Member, followed by a thick reversed polarity magnetozone that extends into the lower part of the Ørsted Dal Member. The remaining part of the Ørsted Dal Member that was sampled has another normal-reversed-normal polarity sequence with a single-sampling level reversed polarity in the first normal magnetozone.

Kent and Clemmensen (1996) suggest that the Malmros Klint Member and lowermost Ørsted Dal Member at Carlsberg Fjord can be correlated with the magnetozones E16 (top) to E19 in the Newark section. This would imply that the section represents only ca. $3.5 \mathrm{~m} . \mathrm{y}$, and would place the studied part of the Fleming Fjord Formation in the late Norianearly Rhaetian (Fig. 3). Age estimates of the Fleming Fjord Formation have previously been based on the sparse occurrence of invertebrate fossils and palynomorphs. Conchostracans in the uppermost Edderfugledal Member and lowermost Malmros Klint
Member were dated to the Carnian or Norian (Defretin-Lefranc, 1969; Grasmück and Trümpy, 1969). Ostracods and pelycopods in the upper part of the Tait Bjerg Beds were dated to early Rhaetian by Grasmück and Trümpy (1969), and palynomorphs from the same unit also indicate an Early Rhaetian age (Clemmensen, 1980b). A diverse assemblage of fossils vertebrates has recently been described from the Malmros Klint and Ørsted Dal members by Jenkins et al. (1994). The fauna includes several species of mammals, prosauropod and theropod dinosaurs, turtles, phytosaurs, pterosaurs, aetosaurs, labyrinthodont amphibians and fishes. The fauna is described as predominantly European in aspect and is of Norian age. Thus palaeontological data support a late Norian-early Rhaetian age of the Fleming Fjord Formation.

\section{Sedimentary facies}

The sedimentary facies in the Fleming Fjord Formation were described by Clemmensen (1980a). A modified facies classification, based on new observations in the 1991, 1992 and 1995 field seasons in the Carlsberg Fjord area, is presented here.

\subsection{Malmros Klint Member}

This unit constitutes a 100-130 m thick relatively monotonous, cliff-forming red-bed unit. It is here

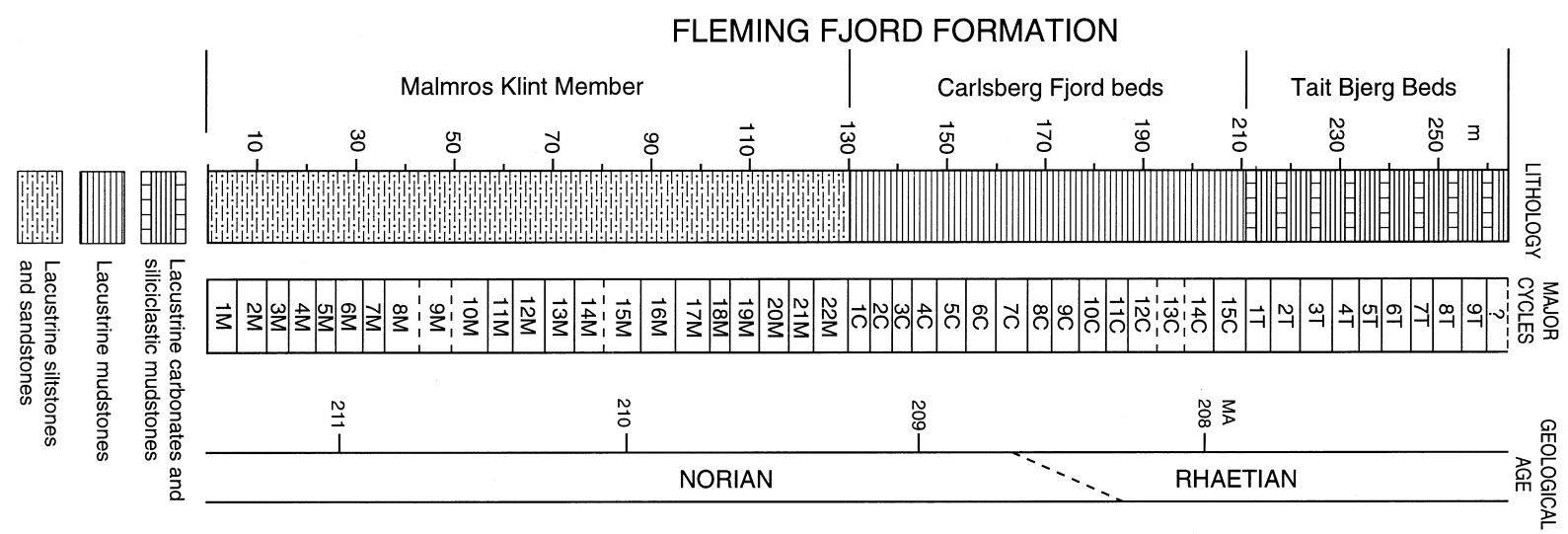

Fig. 3. Simplified stratigraphic column of the studied part of the Fleming Fjord Formation at Tait Bjerg and Macknight Bjerg. Identified major cycles are 100 ka eccentricity cycles. Magnetostratigraphical studies indicate a late Norian to early Rhaetian age for the succession; the duration of the Malmros Klint Member and the Carlsberg Fjord beds is ca. 3.5 m.y. (Kent and Clemmensen, 1996). 
divided into the following dominantly siliciclastic sedimentary facies: (1) intraformational conglomerate; (2) brownish red massive siltstone; (3) greyish red laminated siltstone; (4) reddish grey muddy sandstone with wave-generated structures and bioturbation; (5) yellowish disrupted dolomitic sediment.

\subsubsection{Intraformational conglomerate}

This facies is typically $0.1-0.3 \mathrm{~m}$ thick. It is composed of densely packed millimetre-to-centimetre-size partly rounded mudstone clasts. Transported, fragmentary vertebrate remains are also seen. The facies usually overlies intensively disrupted yellowish dolomitic mudstones. The mudstone clasts probably originated through the erosion of desiccated mudor playa-flats during high-energy events. The facies probably represents several episodes of flooding of the dry mud-flats by lake water.

\subsubsection{Brownish red massive siltstone}

This facies may reach a thickness of more than $1 \mathrm{~m}$. It covers a relatively wide grain size range from clay to fine sand. The facies appears massive in the field apart from thin intervals with horizontal lamination or rare wave ripples. In thin section the sediment appears as a structureless to faintly laminated mudstone with varying amounts of silt- and fine sand-sized quartz grains and mudstone clasts. The silt-sized grains are set in a red-coloured matrix of very fine silt and clay. X-ray diffractograms indicate the common occurrence of authigenic albite in the sediment. The matrix possesses a poorly defined peloidal or clotted texture. Carbonate (calcite and dolomite) typically constitutes approximately $30 \%$ of the sediment. Many intervals contain millimetre-size carbonate nodules or small partly carbonate filled cavities. Inspection of polished hand specimens and thin sections indicates that the facies typically contains tiny white carbonate-filled tubes. The tubes have a rather irregular outline, bifurcate and are mostly oriented subvertically or subhorizontally. Bedding planes commonly display polygonal desiccation features and a large part of the sediment is disrupted by vertical desiccation cracks.

The facies is interpreted as mud flat to shallow lacustrine deposits. Although we have not detected analcime, the abundance of authigenic albite suggests a sodium-rich lake system (cf. Van Houten,
1964). The small nodules and partly filled cavities may represent former evaporite crystals. Subaqeous deposition is indicated by thin horizons with wave ripples, and indirectly by the numerous horizons with desiccation cracks. Subaerial exposure is suggested by the common small tubes interpreted as root structures. The bulk of the sediment is possibly of aeolian origin, and aeolian processes could have supplied both the fine fraction and the silt-sized grains in connection with dust storms. The mixture of silt-sized mineral grains and clay peloids is a feature shared with many Quaternary loess deposits in central Australia (cf. Talbot et al., 1994). Part of the peloids, however, could also have been transported into the basin as pedogenic aggregates by low-energy rivers (cf. Rust and Nanson, 1989, 1991). After deposition the peloids lost much of their identity due to compaction and pedogenic processes resulting in development of clotted texture. Rather similar facies occur in the Late Triassic Mercia Mudstone Group of England; these sediments have been interpreted as polygenic deposits formed by a mixture of lacustrine, fluvial and aeolian processes (Talbot et al., 1994).

This facies formed in a seasonal wetland environment (cf. Wright and Platt, 1995) and is not easily given a depth rank in the sense of Olsen and Kent (1996). The duration of seasonal submergence apparently was an important factor and controlled the nature of most of the sediments in the Fleming Fjord Formation. We therefore define a 'wetness' index ranging from 0 to 5 to characterize the facies. A wetness index of 0 indicates a yearly dry environment, while a wetness index of 5 indicates permanent water coverage. Values between 1 and 4 indicate environments characterized by seasonally variable submergence. On such a scale this facies is given a wetness index of 1-2.

\subsubsection{Greyish red laminated siltstone}

This facies is $0.1-1 \mathrm{~m}$ thick and consists of clay-rich fine to coarse siltstone with horizontal lamination or lenticular bedding. Polygonal mud cracks are seen on most bedding plane surfaces; in vertical sections these structures appear as downward tapering, strongly sinuous slender cracks only a few centimetres long. Aquatic trace fossils are common (cf. Bromley and Asgaard, 1979) and thin layers with conchostracans occur locally. 
The facies is interpreted as a shallow lacustrine deposit. Sedimentation mainly took place from suspension, but occasional wave activity is indicated by the lenticular bedding. The lake dried out frequently. On the wetness scale this facies is given an index of 3-4.

\subsubsection{Reddish grey muddy sandstone with wave-generated structures and bioturbation}

This facies, up to $0.5-1.0 \mathrm{~m}$ thick, consists of fineto medium-grained muddy sandstone with wave-ripple lamination and associated wave-generated structures (Figs. 4 and 5). Scattered centimetre-scale carbonate nodules may occur and the facies is better cemented than the surrounding facies. Strong bioturbation is commonly seen. Various aquatic to terrestrial trace fossils, e.g. Scoyenia and Skolithos are also present (Bromley and Asgaard, 1979). Small desiccation cracks are densely distributed in the main part of the facies, and the upper part of the facies is typically disrupted by large desiccation cracks, $0.2-1$ $\mathrm{m}$ deep. Well-developed root tubes are also seen in the upper part of this facies, and there is typically a gradual transition to the overlying dolomitic sediment. Plateosaurus skeletons were found at four localities in this facies. At least in one example the associated sediment displayed large-scale soft-sediment deformation structures.

This facies clearly originated in shallow waveagitated lacustrine water. Periods of exposure and desiccation were frequent. After deposition this facies was disrupted by intensive desiccation and root growth probably related to a prolonged period of non-sedimentation. Dinosaurs apparently crossed the surface during this period of non-sedimentation and a few of them sank into the wet and soft substrate. This facies is given a wetness index of 3-1 with the lowest index in the upper part of each facies.

\subsubsection{Yellowish disrupted dolomitic sediment}

This rock type, which is a dolomite-rich sandstone or mudstone, is easily seen in the field because of its typical yellowish colour (Fig. 4A,B). More rarely the sediment has an intense red colour. The rock type typically occurs in layers, $1-10 \mathrm{~cm}$ thick. It is always strongly disrupted or even brecciated by well-developed desiccation cracks. The transition from the underlying facies is gradual; upward there may be a sharp or gradational contact to overlying intraforma- tional conglomerates. Vertebrate remains especially of amphibians are relatively common on the top surface of this facies. In thin section the dolomitic sediment has a massive, or more commonly finely stratified appearance. Rare silt-sized quartz grains and mudstone clasts are set in a fine-grained matrix with clotted texture; the matrix contains microcrystalline dolomite and also some calcite. Underlying sediments are typically structureless or display evidence of pedoturbation.

Rather similar rock types are well-described from the Late Triassic Newark basins in North America (Demico and Gierlowski-Kordesch, 1986; Smooth and Olsen, 1988; Smooth, 1991; Gierlowski-Kordesch and Rust, 1994). In agreement with their ideas this rock type is interpreted as the result of very slow aggradation on an exposed playa surface. The surface experienced repeated wetting and drying, dolomite crust formation and extensive desiccation. This rock type and underlying facies can be classified as a paleosol and is given a wetness index of 0 to 1 .

\subsection{Carlsberg Fjord beds}

This $80-115 \mathrm{~m}$ thick red to variegated dominantly siliciclastic rock unit was briefly described by Jenkins et al. (1994) and is composed of the following facies: (1) intraformational conglomerate; (2) redbrown to purple massive mudstone; (3) light reddish or greenish grey mud-peloid siltstone with wave ripple cross-lamination; and (4) light greyish fine to medium-grained quartz-rich sandstone with current-formed cross-stratification.

\subsubsection{Intraformational conglomerate}

There is only one example of this facies in the middle part of the unit. The bed has a maximum thickness of 10-15 cm and occurs on top of a heavily desiccated mudstone. The bed can be traced laterally for more than $1 \mathrm{~km}$ towards the basin margin until it gradually looses its characteristics. The conglomerate is composed of a poorly sorted mixture of relatively large mudstone clasts and transported vertebrate remains set in a sandy matrix (Jenkins et al., 1994).

The bed indicates high-energy flooding of a dry mudflat. From the characteristics of the deposits it is impossible to tell whether the flooding episode was 

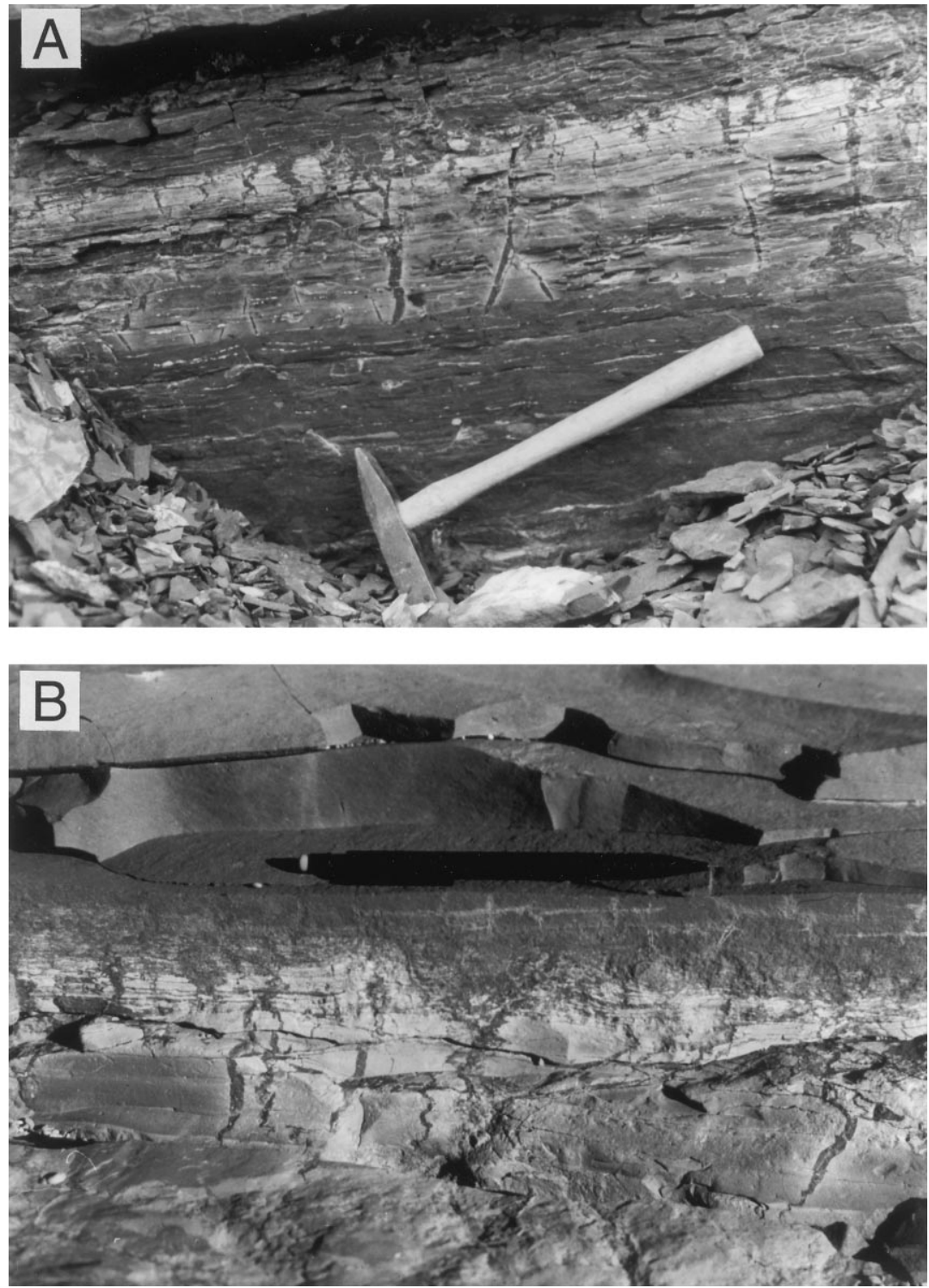

Fig. 4. Sedimentary facies in the Malmros Klint Member. (A) Well-developed light coloured dolomitic sediment (paleosol) underlain by reddish grey muddy sandstone and overlain by weakly laminated red siltstone. There is a poorly developed intraformational conglomerate on top of the dolomitic sediment. (B) Detail of a second dolomitic sediment. Note deep vertical desiccation cracks and the brecciated nature of the upper part of the dolomitic sediment.

of lacustrine or fluvial origin. This facies represents a single depositional event and is not easily given a wetness index.

\subsubsection{Redbrown to purple massive mudstone}

The facies is composed of clayey mudstone, and occurs in units up to ca. $1.5 \mathrm{~m}$ thick. Redbrown mudstones are commonly seen to occur on top of purple mudstones. The facies is structureless or more rarely displays faint horizontal lamination or very small-scale wavy bedding. Thin millimetre- to centimetre-scale siltstone layers are common and may possess low-relief wave ripples, and aquatic trace fossils on the soles, e.g. Cruziana (Bromley and 


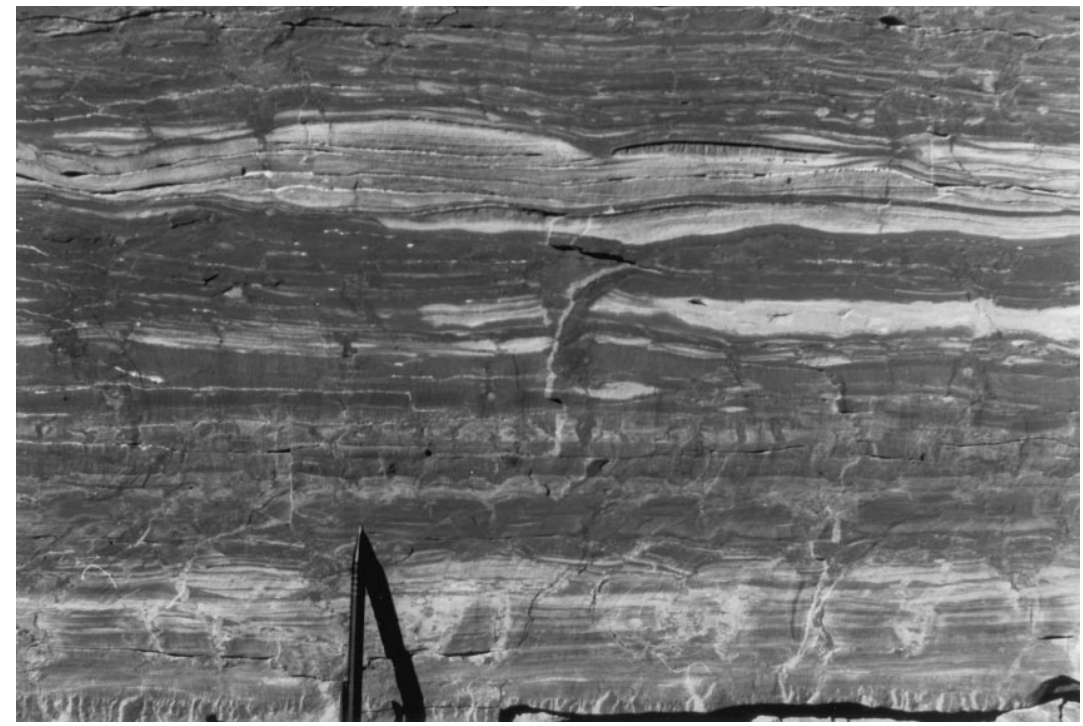

Fig. 5. Sedimentary facies in the Malmros Klint Member. Reddish grey muddy sandstone with horizontal lamination and undulatory lamination. These structures are thought to indicate rather high-energy wave action. Note densely spaced horizons with desiccation cracks indicating episodic sedimentation and frequent periods of subaerial exposure.

Asgaard, 1979). Horizons with desiccation cracks are common and some of the associated mudstone horizons look like very immature vertisols. The massive nature of the mudstones is a very characteristic feature in the field; the mudstones weather to small equi-dimensional sediment pieces and freshly broken surfaces typically display a conchoidal fracture pattern. Close inspection indicates that many beds are intensively bioturbated, whereas other beds display very small-scale root structures much like those seen in the massive siltstones in the Malmros Klint Member. In thin section this facies is seen to be composed of very fine-grained hematite-stained mud displaying a well-developed clotted texture. There are many tiny vugs filled with calcite and/or dolomite. Clastic grains are very rare or totally absent. Vertebrate fossils are preserved in this facies and include amphibian remains (Gerrothorax), lungfish toothplates and skulls, and fragmentary dinosaurs (Jenkins et al., 1994).

The structureless mudstones seem to represent very shallow lake and associated mudflat deposits. Intermittent low-energy wave action is testified by the thin siltstone beds. Subaerial exposure and desiccation is documented by common desiccation cracks and by the supposed tiny root structures. It is sug- gested that part of the silt was windborne material that was trapped in the shallow lake or on vegetated mud flats (cf. Talbot et al., 1994). The clotted texture of the sediment could indicate that much of the mud formed from the accumulation of reworked soil aggregates (cf. Rust and Nanson, 1989; Talbot et al., 1994). Alternatively the clotted texture could have originated in the sediment after deposition by pedogenic processes in a dry steppe climate. The bulk of the facies is given a wetness index of 1 to 2 ; purple mudstones at the base of many mudstone units may represent a wetness index of 3 .

\subsubsection{Light reddish or greenish grey mud-peloid siltstone with wave ripple cross-lamination}

This facies occurs as well-defined siltstone beds, $2-5 \mathrm{~cm}$ thick, of wide lateral continuity. Thin sections show that the facies is composed of silt-sized or more rarely sand-sized mud peloids, a little quartz and some organic material. The well-rounded mud peloids form well-defined millimetre-size laminae that are set in a matrix of calcite and dolomite. The siltstones, which are fine grained and mud-rich, form thin resistant ledges that are easily detectable in the landscape. A chemical analysis of a typical bed indicates a carbonate content of $32 \%$. In spite of 
their thinness individual siltstones typically possess a composite build-up. The lower bedding plane is sharp and weakly erosional. Abundant aquatic trace fossils and tiny tool marks are seen on weathered sole surfaces. A thin intraformational conglomerate $(0.1-1 \mathrm{~cm})$ with millimetre-size mudstone clast commonly occurs at the base of the siltstone. The next interval $(1-2 \mathrm{~cm})$ may show horizontal lamination, small-scale current-formed cross-lamination, or more rarely undulatory or small-scale waveformed cross-lamination. The upper half of the beds $(1-3 \mathrm{~cm})$ always possesses small-scale wave-formed cross-lamination. Thin mudstone films separate individual siltstone divisions. Symmetrical wave ripples are commonly preserved on the upper bedding plane. These wave ripples are WNW-ESE (common) or SW-NE (more rarely) oriented in present coordi- nates. The wave rippled upper bedding plane is cut by polygonal mudcracks. Dinosaur footprints (Fig. 6; Jenkins et al., 1994) and terrestrial trace fossils, e.g. Steinichnus and small stuffed burrows are very common on these upper bedding planes (Bromley and Asgaard, 1979).

The thin siltstone beds represent several episodes of flooding of the mudflats by lake water. Water depth was sufficient to allow the formation of wave ripples. Sedimentation in shallow water was punctuated by periods of subaerial exposure and desiccation. In these periods dinosaurs travelled across the exposed lake beds. The high content of peloids could indicate that much of the sediment represents reworked soil aggregates (cf. Rust and Nanson, 1989; Talbot et al., 1994). This facies has a likely wetness index of 2-3.
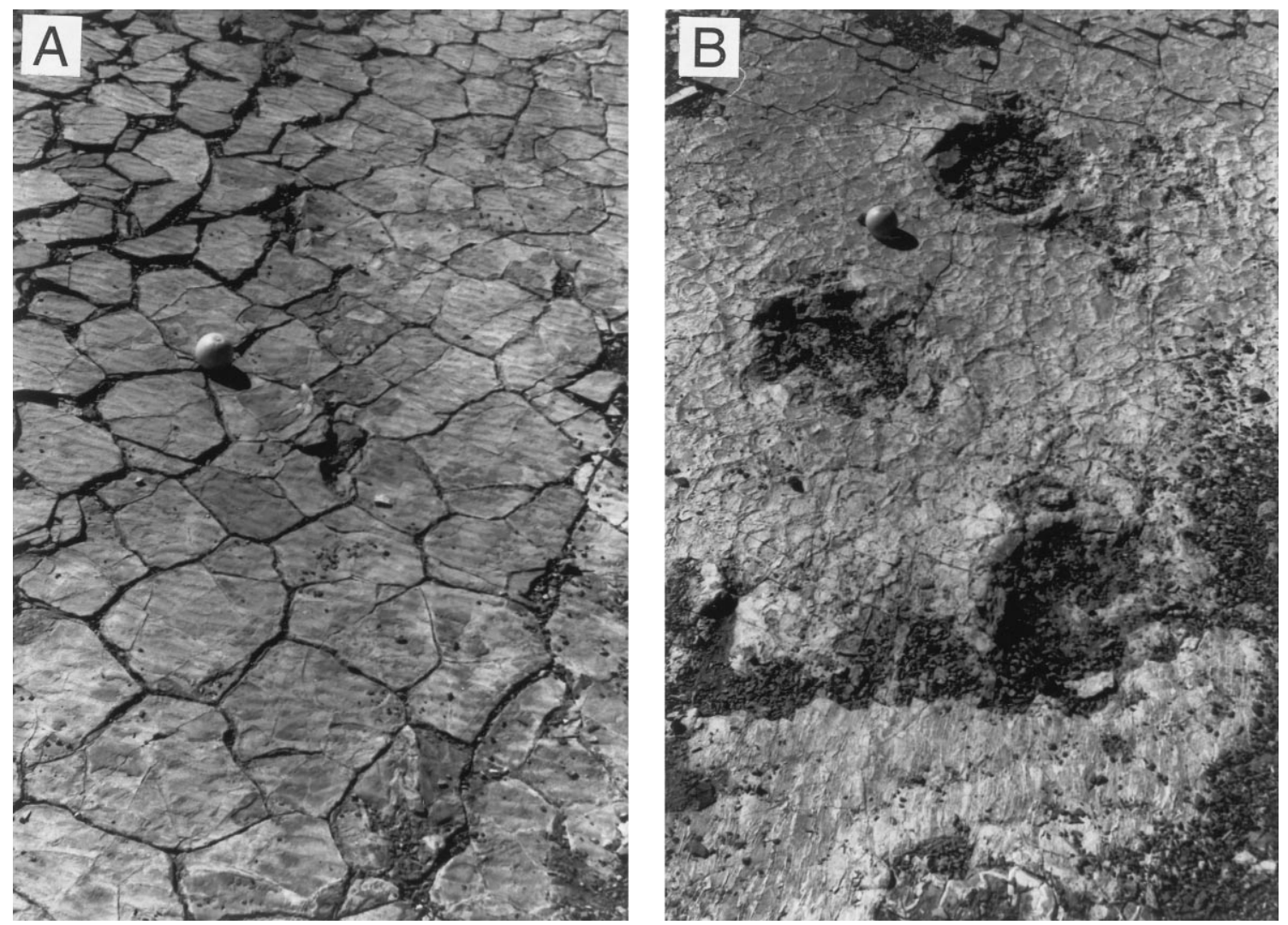

Fig. 6. Sedimentary facies in the Carlsberg Fjord beds and lowermost Tait Bjerg Beds. (A). Thin reddish grey siltstone in uppermost Carlsberg Fjord beds. The upper surface of the siltstone displays wave ripples, desiccation polygons and a dinosaur trackway. Orange for scale. (B) Thin greenish silty sandstone in lowermost Tait Bjerg Beds. Note large dinosaur footprints and tiny polygonal desiccation cracks. Orange for scale. 


\subsubsection{Light greyish fine- to medium-grained quartz-rich sandstone with current-formed cross-bedding}

This facies is relatively rare and only represented by two or three examples in the Carlsberg Fjord beds. Two well-defined sandstones of this type occur in the basal part of the unit and one sandstone occurs near the top of the unit. The sandstones are quartzrich and have a thickness of 0.2 to $0.5 \mathrm{~m}$, and in one case up to $1 \mathrm{~m}$. The lower contact may be gradational to the underlying mudstones or clearly erosional. Intraformational conglomerates of mudstone clasts and, more rarely, waterworn vertebrate remains are seen near the base of the erosional sandstone units. The middle part of the sandstone typically contains largescale or more commonly small-scale current-formed cross-stratification. Isolated small channel fills are also seen. The upper part of the sandstones contains as a rule small-scale wave-formed structures. Parts of the sandstones are bioturbated and Fuersichnus-like copper-impregnated trace fossils have been seen in one example. The current-generated structures show a relatively wide range of palaeocurrent directions with a dominance towards the north.

The sandstones formed during episodes of high sand supply to the lake. The sedimentary characteristics of the sandstone bodies suggest that initial deposition took place in distributary channel and mouth bar environments in a marginal lake setting. The final phase of deposition took place in shallow wave-agitated water. There is evidence of periodic, possibly seasonal, exposure during formation of the deposit, but it is difficult to assign wetness index to this facies.

\subsection{Tait Bjerg Beds}

This unit forms a 50-65 m thick succession of interbedded marlstones and siliciclastic mudstones. At many places Tait Bjerg Beds weather in a characteristic step-like manner with the marlstones forming the resistant ledges. The unit has not yet been the subject of a detailed facies analysis, but the following facies are recognized: (1) massive to faintly laminated red mudstone; (2) partly laminated greenish mudstone; (3) laminated greyish mudstone; (4) thin wave-rippled sandstone; (5) intraformational conglomerate; and (6) marlstone.

\subsubsection{Massive to faintly laminated red mudstone}

This facies is almost identical to the massive mudstone facies of the Carlsberg Fjord beds. Thus the sediment was probably deposited in very shallow lake and mudflat environments. The facies represents a wetness index of 1-2.

\subsubsection{Partly laminated greenish mudstone}

This facies is transitional to the above facies, but it possesses greenish or brownish grey colours and is better laminated. It was apparently deposited in slightly deeper lake water than the red mudstones. Periods of subaerial exposure were less common and the facies is given a wetness index of 3 .

\subsubsection{Laminated greyish mudstone}

This facies is transitional to the greenish mudstone facies. It is typically laminated and possesses greyish colours ranging from medium light grey to medium dark grey. The sediment was deposited in a relatively deep semi-perennial to perennial lake rarely subject to desiccation and is given a wetness index of 4-5.

\subsubsection{Thin wave-rippled sandstone}

This facies is composed of reddish or greenish grey silty sandstones, $2-5 \mathrm{~cm}$ thick, with wave-ripple lamination. Upper bedding planes commonly display polygonal mud-cracks and dinosaur footprints (Fig. 6). The facies probably represents one or a few episodes of flooding of dry mudflats separated by periods of exposure; it is assigned a wetness index of 2-3.

\subsubsection{Intraformational conglomerate}

This facies occurs as centimetre-thick layers of relatively small intraformational mudstone and limestone clasts. Fish and amphibian remains are locally present. Also this facies probably formed in connection with flooding of exposed mudflats, but it is not easily given a wetness index.

\subsubsection{Marlstone}

This facies forms beds with a thickness between 0.1 and $0.8 \mathrm{~m}$. It weathers in yellowish colours, but is grey on freshly broken surfaces. The facies contains a fair amount of siliciclastic material and the carbonate content of the sediment varies between 
34 and $71 \%$. Chemical analysis and X-ray diffractograms indicate that both calcite and dolomite are present. In thin sections the marlstone is seen to be composed of micrite and microspar with a varying amount of silt-size quartz grains. The sediment has a well-defined peloidal texture. The marlstone has a transitional boundary to the underlying siliciclastic mudstone (most commonly facies 2 or 3 ) and a sharp, but sometimes undulatory, boundary to overlying facies. This facies is locally rich in vertebrate fossils, principally amphibian and fish remains but also contains mammals (Jenkins et al., 1997). The marlstone appears massive in the field, but the upper part of the sediment is commonly heavily brecciated and upper bedding planes may display desiccation polygons. This is especially the case in the lower part of the Tait Bjerg Beds where the marlstones also contain root structures and display dinosaur footprints. These sediments were probably deposited in a shallow lake. There is evidence of shallowing during deposition of these marlstones and the intense brecciation and the dinosaur footprints at the top of the sediment indicates a period of subaerial exposure. The sediments are given a wetness index of 2 to 1 . Marlstones in the upper part of the Tait Bjerg Beds commonly lack brecciation and other evidence of subaerial exposure and therefore seem to have been formed in a semi-perennial lake, they have a wetness index of 3.

\section{Depositional cycles and palaeoclimate}

All rock units in the Fleming Fjord Formation are cyclically bedded (cf. Clemmensen, 1978, 1979, 1980a; Jenkins et al., 1994). Most of the cycles possess a characteristic weathering profile enabling their identification in the field (Fig. 7). The cliff-forming nature of the Malmros Klint Member makes it impossible to measure a complete detailed centimetrescale sedimentary log. The collected data therefore do not allow a spectral analysis of facies and wetness ranks, but only a study of overall cycle characteristics and cycle thicknesses. Data on cycle thicknesses are from one major and several subsidiary sections at Tait Bjerg. In the Carlsberg Fjord beds and Tait Bjerg Beds exposures are commonly more suitable for detailed centimetre-scale studies of facies. In the Carlsberg Fjord beds, however, there is little variation in facies and wetness index with time. The study of cyclicity in this member is therefore primarily based on a record of cycle thicknesses. Data on cyclicity in this unit are from one complete section at a mountain ridge north of Macknight Bjerg and from several subsidiary sections at Tait Bjerg. Data on cyclicity in the Tait Bjerg Beds are from one complete section at the mountain ridge north of Macknight Bjerg.
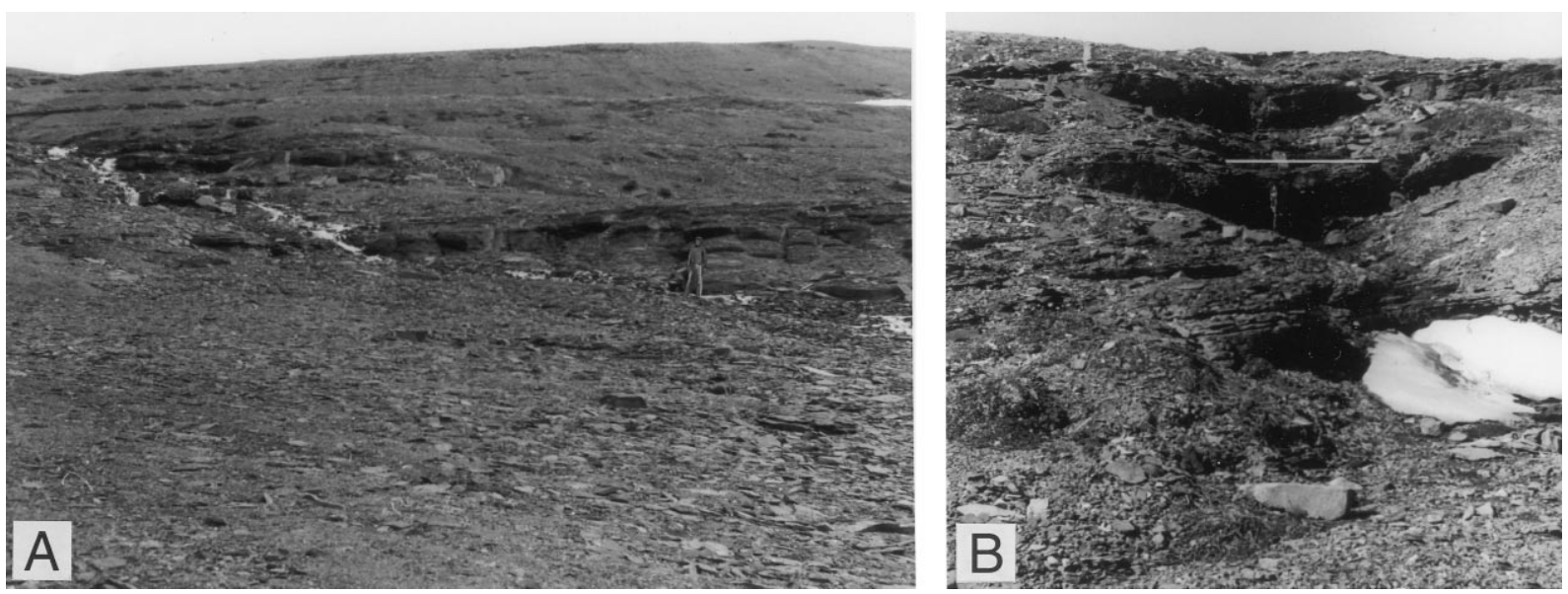

Fig. 7. Sedimentary cycles in the Malmros Klint Member. (A) Major $5.9 \mathrm{~m}$ cycles at the south side of Tait Bjerg. Geologist for scale. (B) Minor (basic) $1.6 \mathrm{~m}$ cycles at the south side of Tait Bjerg. Measure stick $(1.5 \mathrm{~m}$ ) for scale. The top of the cycles (both major and minor ones) are composed of dolomitic sediments. 


\subsection{The Malmros Klint Member}

This member displays a composite cyclicity. Based on measured thicknesses of cycles in the field, we identify the following statistically significant depositional cycles: $1.6,5.9$, and $(25 \mathrm{~m})$. Most cycles are characterized by a lower siltstone-rich unit and an upper sandstone-rich unit topped by a dolomitic paleosol. Due to the better cemented nature of the sandstones and especially the paleosols these sediments are more resistant to weathering than the underlying mudrocks. This results in a characteristic steplike nature of the weathering profile (Fig. 7). In the field the most prominent cycles have thicknesses between ca. 5 and ca. $7 \mathrm{~m}$ (mean of observations = $5.89 \mathrm{~m}$; confidence interval for population $=5.65$ $6.14 \mathrm{~m}$; Fig. 8). At Tait Bjerg the member is composed of 22 superimposed $5.9 \mathrm{~m}$ cycles (Fig. 3). In good exposures it is apparent that the $5.9 \mathrm{~m}$ cycles are composed of a number (typically 3-6) of thinner cycles. These thinner cycles are between ca. 1 and ca. $2 \mathrm{~m}$ thick (mean of observations $=1.60$ $\mathrm{m}$; confidence interval for population $=1.54-1.65$ m; Fig. 9). Also these cycles are sometimes seen to be composed of thinner cycles with thicknesses between 0.25 and $0.6 \mathrm{~m}$. Groups of $5.9 \mathrm{~m}$ cycles may finally form $25 \mathrm{~m}$ cycles as revealed by examination of partly snow-covered mountain slopes. Data on thicknesses of the $5.9 \mathrm{~m}$ cycles actually indicate that this group is composed of two well-defined subpopulations with mean thicknesses of 5.3 and 6.5 m (Fig. 8). In a similar way it appears that the 1.6 $\mathrm{m}$ cycles are composed of two subpopulations with mean thicknesses of 1.5 and $2.1 \mathrm{~m}$ (Fig. 9). Because the thicknesses of these subcycles overlap, none of these subpopulations could be tested statistically.

The basic $1.6 \mathrm{~m}$ cycles are most characteristically composed of a basal intraformational conglomerate with worn vertebrate fragments overlain by massive siltstone (Fig. 10). The middle part is typically composed of thinly bedded siltstones with lamination while the upper part is a sandstone with wave-generated structures. At the top of the cycles there is a dolomitic paleosol (Fig. 10). All facies and in particular the sandstones in the upper part of the cycles display closely spaced horizons with desiccation cracks.

The sedimentary characteristics of the cycles suggest at least two orders of climatic variation. The
Tait Bjerg Beds
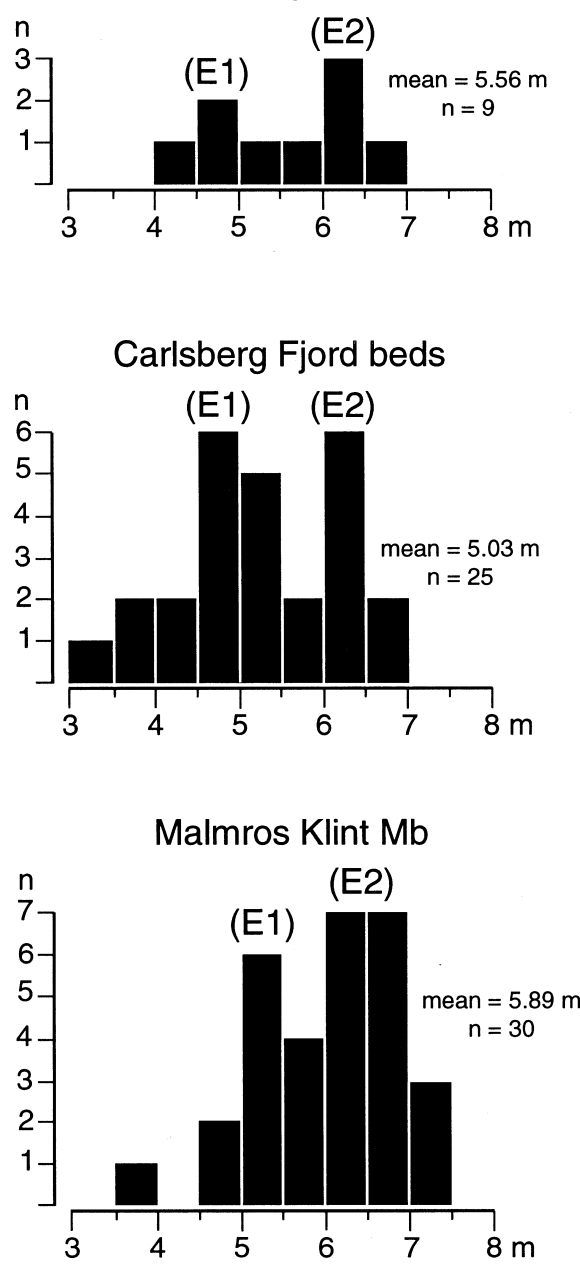

Fig. 8. Distribution of major cycle thicknesses, Malmros Klint Member, Carlsberg Fjord beds and Tait Bjerg Beds. Note the apparent bimodal nature of the distributions. These cycles are interpreted as eccentricity; the bimodal nature of the distributions could reflect the presence of both 95 (E1) and 123 (E2) ka cycles.

densely spaced desiccation cracks in all facies indicate frequent subaerial exposure of the lake, possibly on a seasonal scale. The composite metre-scale cyclicity indicates systematic climatic changes on an intermediate time scale. Palaeomagnetic studies by Kent and Clemmensen (1996) suggest that the 130 $\mathrm{m}$ thick member represents ca. 2.0 m.y. of the late Norian (Fig. 3). According to this time estimate the $1.6 \mathrm{~m}$ cycles have a duration of $25 \mathrm{ka}$, the $5.9 \mathrm{~m}$ cycle a duration of $91 \mathrm{ka}$ and the $25 \mathrm{~m}$ cycle a duration of $385 \mathrm{ka}$. These durations fall within the time 

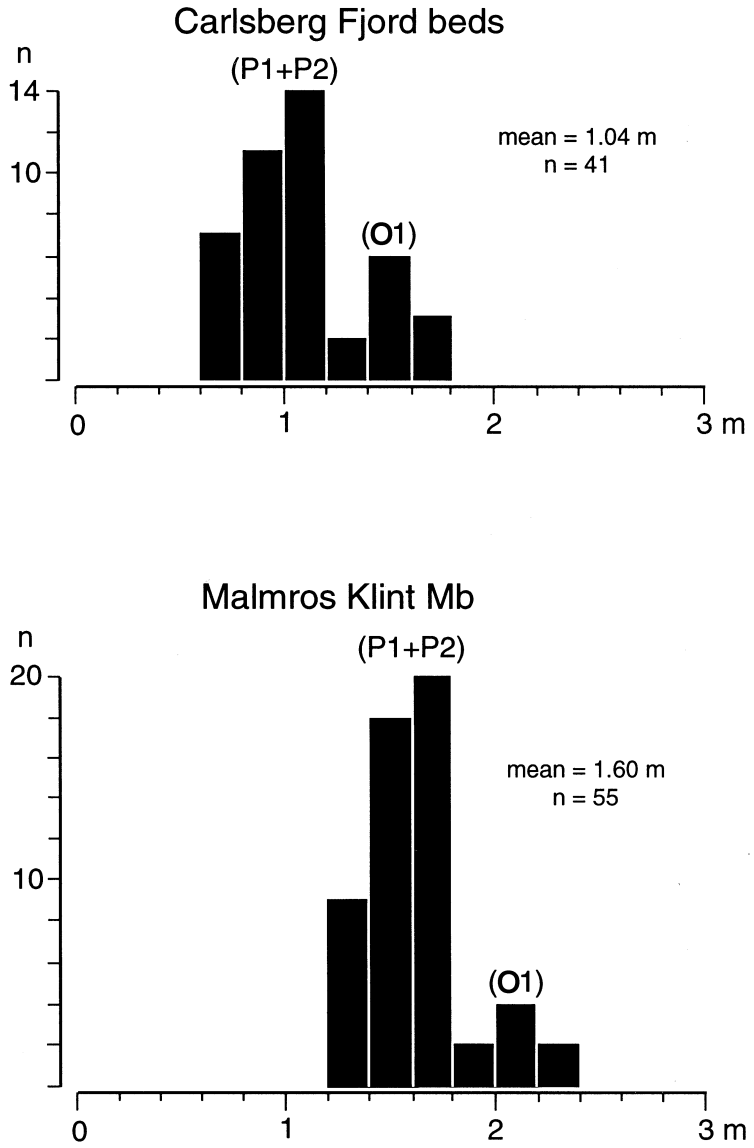

Fig. 9. Distribution of minor (basic) cycle thicknesses, Malmros Klint Member and Carlsberg Fjord beds. Note the apparent bimodal nature of the distributions. The major peak is thought to reflect the precession $(\mathrm{P} 1+\mathrm{P} 2)$ cycles, while the subsidiary peak may reflect the obliquity $(\mathrm{O} 1)$ cycle.

scale of orbital control (Berger and Loutre, 1994). The bundling of 3 to 6 basic $1.6 \mathrm{~m}$ cycles into the thicker $5.9 \mathrm{~m}$ cycles also suggest Milankovitch control on sedimentation (cf. De Boer and Smith, 1994). In the Triassic the main periods of the precession cycles have been estimated to be about 18 and 21.5 $\mathrm{ka}$ (mean of $19.8 \mathrm{ka}$ ), while the main obliquity cycles has been calculated to be about $36 \mathrm{ka}$ and the eccentricity cycles to be about 95 and $123 \mathrm{ka}$ (Berger and Loutre, 1994). A calculation of ratios between cycle thicknesses in the member (cf. Olsen, 1986) yields values that compare well with the ratios between the Triassic orbital cycles (Table 1).

Thus the mode at $1.5 \mathrm{~m}$ seems to represent the two precession-related cycles around $20 \mathrm{ka}$, while the $2.1 \mathrm{~m}$ cycles could represent the $36 \mathrm{ka}$ obliquity cycles (Fig. 9). The mode at $5.9 \mathrm{~m}$ is probably the eccentricity cycle around $100 \mathrm{ka}$ (Fig. 8), and the 25 $\mathrm{m}$ cycle the 400 ka eccentricity cycle (Table 1 ). It is of interest to note that the $5.9 \mathrm{~m}$ cyclicity apparently is composed of two subcycles at 5.3 and $6.5 \mathrm{~m}$ (Fig. 8). The ratio between these cycles $(1: 1.23)$ matches very well the ratio $(1: 1.29)$ between the two eccentricity cycles of 95 and 123 ka.

Assuming that this interpretation is correct, it is possible to calculate accumulation rates; they vary between 54 and $78 \mathrm{~mm} / \mathrm{ka}$ with a member average of $63 \mathrm{~mm} / \mathrm{ka}$ (Table 2). The deduced accumulation rates for the Malmros Klint Member are low but compare quite well with data from the Middle Devonian Orcadian lake system (110-250 mm/ka; Alt et al., 1995), the Rotliegend lake system (60-110 $\mathrm{mm} / \mathrm{ka}$; Yang and Baumfalk, 1994), the Late Triassic Newark lake system (140-210 mm/ka; Olsen and Kent, 1996), and the Eocene Green River lake system $(120 \mathrm{~mm} / \mathrm{ka}$; Fischer and Roberts, 1991).

The interpretation of the cyclicity as orbitally controlled allows estimates of the duration of the Malmros Klint Member. The calculations indicate that the member (130 m thick) was formed in a little more than 2 m.y. (Table 1). Clearly this age estimate requires that there are no major hiatus surfaces within the member.

The basic $1.6 \mathrm{~m}$ cycle reflects systematic changes in the lacustrine environment probably related to variations in precipitation and runoff. These climatic variations were apparently controlled by orbital change (20-36 ka time scale). The basal intraformational conglomerate represents a regional flooding surface and records the first phase of a climate shift from dry to humid. The overlying structureless siltstones are ephemeral lake and mudflat deposits formed during a gradually rising lake level and a continued change towards a more humid climate. The laminated siltstones apparently formed in a shallow lake and the climate was now relatively humid. The uppermost sandstone-rich deposits were formed during a gradually falling lake level and they record a change towards a more dry climate. Finally the uppermost dolomitic palaeosol record pedogenic processes on a very slowly aggrading or non-depositional playa surface during a dry climate phase. 


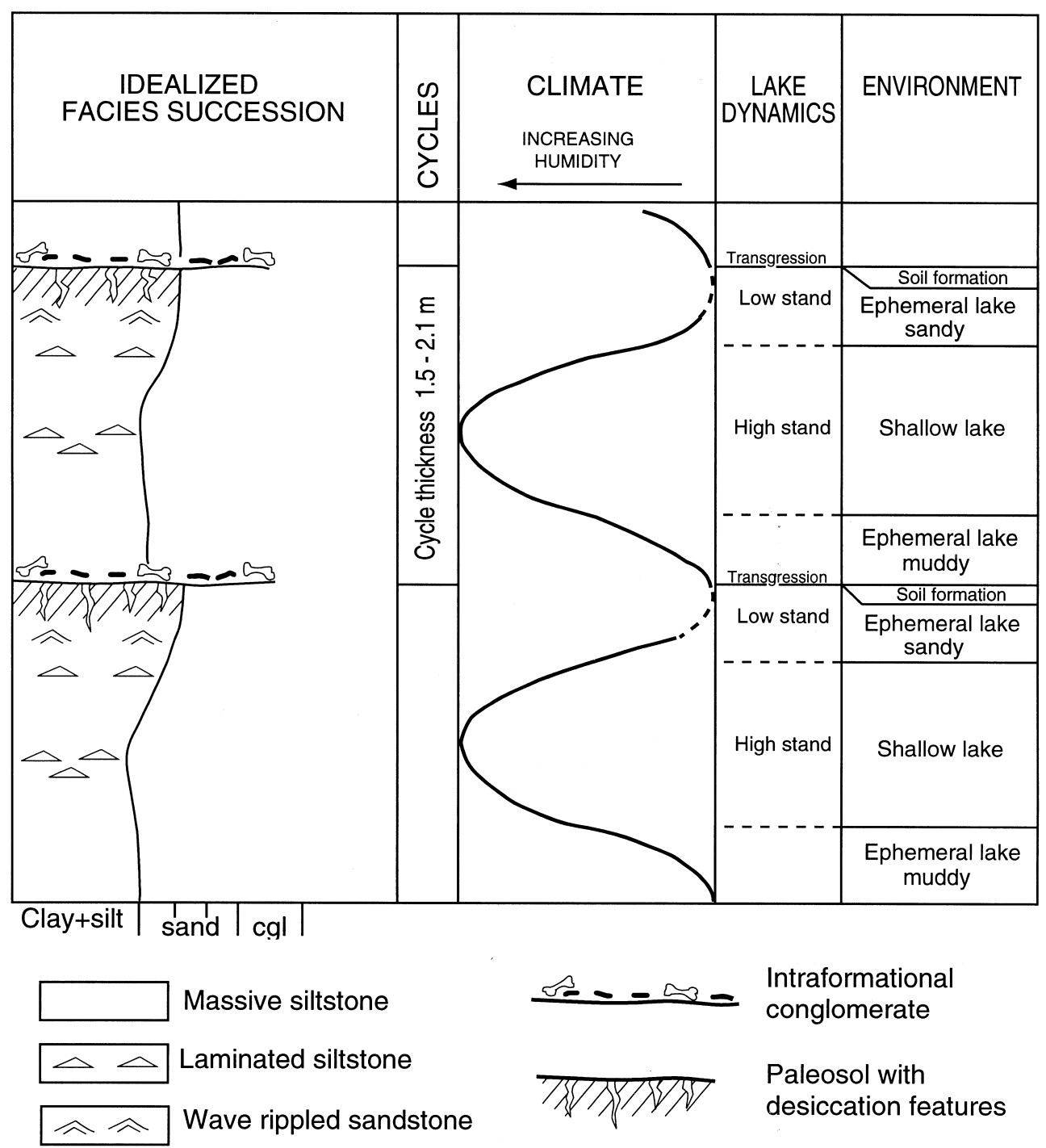

Fig. 10. Idealized facies succession and depositional cycles in the Malmros Klint Member. The facies development is related to climatic change (20 and $30 \mathrm{ka}$ cycles) and to lake dynamics.

The sedimentary characteristics of the Malmros Klint cycle indicate that the lake always was shallow and suffered periodic (possibly seasonal) desiccation even during the most humid climatic phases. During the most arid climatic phase the lake was completely dry. The scarce evidence of evaporites and the common occurrence of trace fossils indicate that lake water at least seasonally was of low salinity. From cycle characteristics we infer that the climatic conditions in the basin varied from dry desert-like (completely dry lake) to dry steppe-like (shallow to ephemeral lake) during each orbital (precession or obliquity) cycle.

\subsection{The Carlsberg Fjord beds}

This rock unit also displays a composite cyclicity (Fig. 11). Statistical significant cycles are 1.0 and 5.0 $\mathrm{m}$ thick; the $25 \mathrm{~m}$ cycles have not been identified. In this rock unit the most prominent cycles are ca. 4-6 $\mathrm{m}$ thick (mean of observations $=5.03 \mathrm{~m}$; confidence 
Table 1

Orbital periods and sedimentary cycles, Upper Triassic Malmros Klint Member

\begin{tabular}{|c|c|c|c|c|c|c|c|c|}
\hline Item & P1 & $\mathrm{P} 1+\mathrm{P} 2$ & $\mathrm{P} 2$ & $\mathrm{O} 1$ & E1 & $\mathrm{E} 1+\mathrm{E} 2$ & E2 & E3 \\
\hline $\begin{array}{l}\text { Late Triassic periods } \\
\text { (ka) }\end{array}$ & 18 & 19.8 & 21.5 & 36 & 95 & 109 & 123 & 413 \\
\hline Ratios & & 1 & & 1.8 & & 5.5 & & 20.9 \\
\hline Cycles (m) & & 1.5 & & 2.1 & & 5.9 & & $(25)$ \\
\hline Ratios & & 1 & & 1.4 & & 3.9 & & $(16.7)$ \\
\hline Member age & & 1.7 & & 2.2 & & 2.4 & & $(2.1)$ \\
\hline sedimentary cycles $(\mathrm{Ma})$ & & & & 2.1 (mean) & & & & \\
\hline $\begin{array}{l}\text { Member age } \\
\text { palaeomagnetics }(\mathrm{Ma})\end{array}$ & & & & $\sim 2.0$ & & & & \\
\hline
\end{tabular}

$\mathrm{P} 1$ and $\mathrm{P} 2=$ precession cycles; $\mathrm{O} 1=$ obliquity cycles; E1, E2 and E3 = eccentricity cycles; P1 + P2 = average of P1 and P2; E1 + E2 $=$ average of E1 and E2.

Table 2

Deduced accumulation rates $(\mathrm{mm} / \mathrm{ka})$ based on cyclostratigraphic and magnetostratigraphic analyses, Upper Triassic Fleming Fjord Formation

\begin{tabular}{lllll}
\hline Item & \multicolumn{2}{c}{ Cyclostratigraphy } & & Magnetostratigraphy \\
\cline { 2 - 5 } & $\mathrm{P} 1+\mathrm{P} 2$ & $\mathrm{O} 1$ & $\mathrm{E} 1+\mathrm{E} 2$ & \\
\hline Tait Bjerg Beds & - & - & 51 & - \\
Carlsberg Fjord beds & 47 & 44 & 46 & 50 \\
Malmros Klint Member & 78 & 58 & 54 & \\
\hline
\end{tabular}

interval of population $=4.70-5.34 \mathrm{~m}$; Fig. 8). These cycles typically form major step-like landscape elements, but these steps are less well defined than in the underlying member sometimes making a correct identification of the cycles difficult. At the main locality the member is composed of 15 stacked 5.0 $\mathrm{m}$ cycles (Fig. 3). All $5.0 \mathrm{~m}$ cycles are composed of a number (typically 3-6) of basic cycles with thicknesses between 0.6 and $1.8 \mathrm{~m}$ (mean of observations $=1.04 \mathrm{~m}$; confidence interval of population $=0.96-1.12 \mathrm{~m}$; Fig. 9). In good exposures it can be seen that some of the basic cycles are composite with subcycles having thicknesses between 0.15 and $0.3 \mathrm{~m}$. A study of the thickness distribution of the $1.0 \mathrm{~m}$ cycles shows that this group of cycles apparently is composed of two subpopulations with mean thicknesses of 0.9 and $1.6 \mathrm{~m}$ (Fig. 9). In a similar way it appears that the $5.0 \mathrm{~m}$ cyclicity is composed of subpopulations with a mean thickness of 4.75 and $6.25 \mathrm{~m}$ (Fig. 8). It has not been possible to test these subpopulations statistically because the thicknesses of the subcycles overlap.
The basic $1.0 \mathrm{~m}$ cycles are composed of a lower clay-rich mudstone unit and an upper relatively thin $(2-5 \mathrm{~cm})$ siltstone unit. The siltstones form resistant ledges of great lateral continuity which define the cyclicity in the field (Fig. 11). The mudstones vary in colour from redbrown to purple. Purple mudstones typically occur in the lower or middle part of the cycles, but individual cycles show much variation. Both mudstones and siltstones contain abundant desiccation features.

Also in this rock unit there is evidence of seasonal as well as intermediate-term changes in climate. Palaeomagnetic studies suggest that the $82 \mathrm{~m}$ thick Carlsberg Fjord beds most likely represents ca. 1.5 m.y. of the late Norian-early Rhaetian (Fig. 3). The $1.0 \mathrm{~m}$ cycles therefore seem to have a duration of $18 \mathrm{ka}$ and the $5.0 \mathrm{~m}$ cycles a duration of $91 \mathrm{ka}$. In agreement with the interpretation of the composite cyclicity in the underlying member, we therefore interpret the composite cyclicity in the Carlsberg Fjord beds as the result of orbital variation. Calculations of ratios of cycle thicknesses support this interpretation 


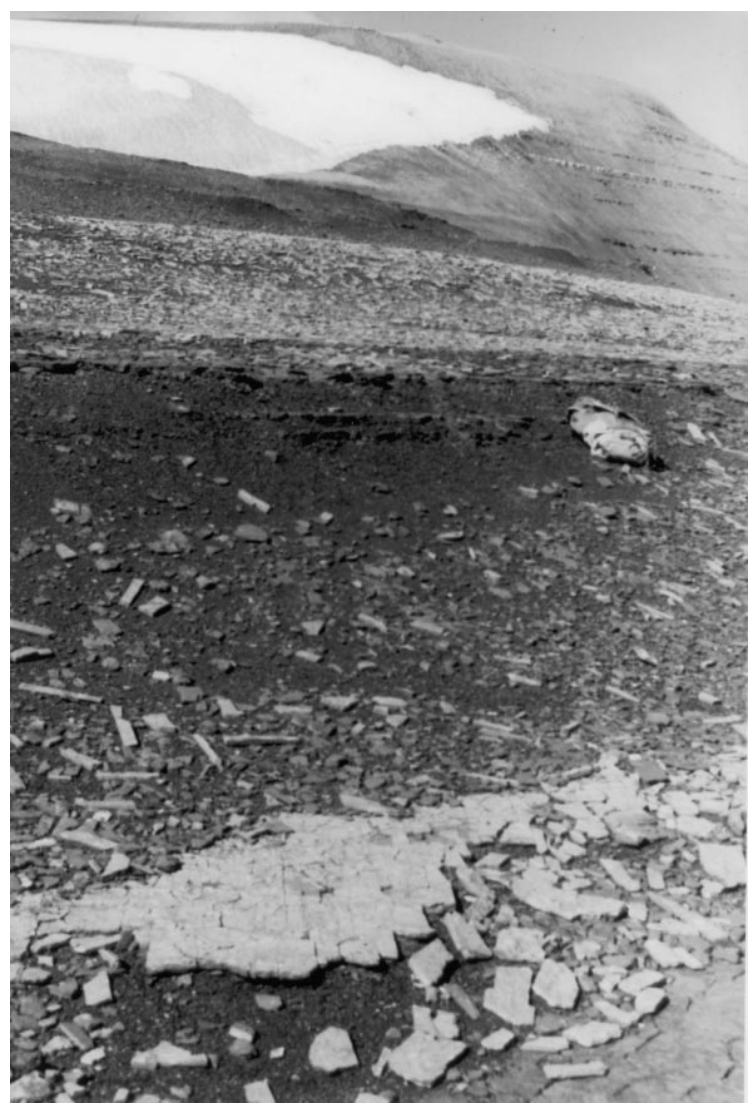

Fig. 11. Minor (basic) $1.0 \mathrm{~m}$ cycles in the Carlsberg Fjord beds, mountain ridge north at Macknight Bjerg. The cycles are defined by the repeated appearance of light coloured siltstones. Intervening sediments are massive purple to redbrown mudstones. Rucksack for scale.

(Table 3). Thus the $0.9 \mathrm{~m}$ cycle is interpreted as 18 and $21.5 \mathrm{ka}$ precession cycles, while the $1.6 \mathrm{~m}$ cycle could represent the $36 \mathrm{ka}$ obliquity cycle. The $5.0 \mathrm{~m}$ cycle is interpreted as the 100 ka eccentricity cycle. The 400 ka cycle has not been identified.

Based on this interpretation, we calculate that the accumulation rate during deposition of the Carlsberg Fjord beds varied between 44 and $47 \mathrm{~mm} / \mathrm{ka}$ (Table 2). The identification of various orbitally controlled cycles in the Carlsberg Fjord beds makes it possible to estimate the duration of the rock unit. At the mountain north of Macknight Bjerg the unit has a thickness of $82 \mathrm{~m}$ and was apparently deposited in ca. 1.8 m.y. (Table 3).

The basic $1.0 \mathrm{~m}$ cycles are of relative monotonous appearance suggesting little change in climate and lake environment on a 20-36 ka time scale. The purple mudstones at the base of the cycles probably were deposited in a more frequently submerged environment (more humid climate) than the overlying redbrown mudstones (more dry climate), but lake depths were always very shallow and subaerial exposure frequent (Fig. 12). The thin siltstone beds separating the mudstones are interpreted as flooding deposits formed during climatic shifts from dry to more humid (Fig. 12). The rare intraformational conglomerates with numerous transported vertebrate remains formed in a similar way but during single and probably catastrophic events.

Thus it appears that climate and in particular the amount of precipitation did not change much during the orbital cycle. Seasonal changes in climate (precipitation) and lake environment were probably more pronounced and may well have blurred most evidence of astronomically forced changes in climate and depositional conditions in the sediment. From the cycle characteristics, we infer that the climate could be characterized as dry steppe-like, but the absence of evaporites suggests that lake water was rarely saline.

\subsection{The Tait Bjerg Beds}

The cyclicity of this member has not yet been studied in detail. From existing data, however, it is evident that also this unit is characterized by a composite cyclicity. The most obvious cycles have thicknesses between 4.5 and $6.5 \mathrm{~m}$ (mean of observations $=5.56 \mathrm{~m}$; confidence interval of population $=5.07-6.04 \mathrm{~m}$; Fig. 8). These cycles consist of siliciclastic mudstones overlain by marlstones (Fig. 13). The marlstones form thin resistant ledges and define the cyclicity in the field. Subcycles are also present and they have thicknesses between 0.9 and $2.4 \mathrm{~m}$ (mean of observations $=1.57 \mathrm{~m}$; it is not possible to calculate a confidence interval). This group of subcycles appear to be composed of different cycle populations like in the former rock unit, but the sample population is too limited to be tested statistically.

The characteristics of the $5.6 \mathrm{~m}$ cycles vary systematically upward in the succession. At the base of the Tait Bjerg Beds a typical cycle is composed of lowermost redbrown mudstones overlain by brownish or greenish mudstones and topped by yellowish weathering marlstones. Desiccation features are 
Table 3

Orbital periods and sedimentary cycles, Upper Triassic Carlsberg Fjord beds

\begin{tabular}{|c|c|c|c|c|c|c|c|c|}
\hline Item & $\mathrm{P} 1$ & $\mathrm{P} 1+\mathrm{P} 2$ & $\mathrm{P} 2$ & $\mathrm{O} 1$ & E1 & $\mathrm{E} 1+\mathrm{E} 2$ & E2 & E3 \\
\hline $\begin{array}{l}\text { Late Triassic periods } \\
(\mathrm{ka})\end{array}$ & 18 & 19.8 & 21.5 & 36 & 95 & 109 & 123 & 413 \\
\hline Ratios & & 1 & & 1.8 & & 5.5 & & 20.9 \\
\hline Cycles (m) & & 0.9 & & 1.6 & & 5.0 & & - \\
\hline Ratios & & 1 & & 1.8 & & 5.6 & & - \\
\hline $\begin{array}{l}\text { Member }{ }^{\mathrm{a}} \text { age } \\
\text { sedimentary cycles (Ma) }\end{array}$ & & 1.8 & & $\begin{array}{l}1.8 \\
1.8 \text { (mean) }\end{array}$ & & 1.8 & & - \\
\hline $\begin{array}{l}\text { Member age } \\
\text { palaeomagnetics (Ma) }\end{array}$ & & & & $\sim 1.5$ & & & & \\
\hline
\end{tabular}

a $82 \mathrm{~m}$ at Raceway locality.

common especially in the redbrown mudstones and in many of the marlstones. In the upper part of Tait Bjerg Beds the cycles are composed of rather monotonous grey mudstones overlain by yellowish weathering marlstones.

The sedimentary characteristics of the cycles suggest seasonal and probably also orbitally controlled lake sedimentation. We have no palaeomagnetic data from the Tait Bjerg Beds and therefore we do not know the duration of this unit. The composite cyclicity in the Tait Bjerg Beds is very similar to the cyclicity in the underlying units. The dominant 5.6 $\mathrm{m}$ cyclicity is therefore interpreted as the $100 \mathrm{ka}$ cyclicity and probably encompasses both the 95 and 123 ka cyclicity (Fig. 8). The basic $1.6 \mathrm{~m}$ cycles are interpreted as both precession (18 and $21.5 \mathrm{ka}$ ) cycles and obliquity (36 ka) cycles. The upward change in composition of the $5.6 \mathrm{~m}$ cycles clearly indicates a change in environment towards a deeper and more permanent lake. This change is thought to be climatically controlled and to be the result of increased precipitation with time.

Based on this interpretation it is calculated that the accumulation rate during deposition of the Tait Bjerg Beds was about $51 \mathrm{~mm} / \mathrm{ka}$, or similar to the accumulation rate characterizing the two underlying rock units. At the locality examined in some detail (mountain north of Macknight Bjerg), the Tait Bjerg Beds are ca. $53 \mathrm{~m}$ thick; the duration of the unit is therefore about 1 m.y. The studied part of the Fleming Fjord Formation (Malmros Klint and Ørsted Dal members along Carlsberg Fjord) would therefore have been deposited in about $5 \mathrm{~m} . \mathrm{y}$. or less. It is evident from the lithological composition of the cycles that they were deposited during important climatic variations. We suggest that the $5.6 \mathrm{~m}$ cycles in the lower part of the unit were formed during relative large variations in lake level. The cycle base is defined by the thin wave-rippled sandstones or intraformational conglomerates and it is suggested that these beds formed during flooding episodes during climatic shifts from dry towards more humid. The overlying red mudstones probably formed during rising lake level (transitional dry-humid climate), the brownish or greenish mudstones are highstand deposits (humid climate) and the marlstones formed during falling lake level (transitional humid-dry climate or dry climate). Upper bedding planes of these marlstones commonly carry dinosaur footprints indicating periods of subaerial exposure The $5.6 \mathrm{~m}$ cycles in the upper part of the unit clearly formed in a perennial lake. The grey mudstones probably formed during high lake levels (humid climate), while the marlstones are thought have formed during low lake levels (less humid climate). We have not seen any dinosaur footprints on these marlstones in the upper part of the unit.

From the sedimentary characteristics of the cycles it is obvious that lake environment changed with time from relatively shallow and ephemeral to semi-perennial to relatively deep and perennial. The semi-perennial to perennial character of the lake suggests a more humid climate of deposition and we infer that deposition of the Tait Bjerg Beds took place in a climate that gradually changed from dominantly dry steppe-like to dominantly warm moist temperate. During each orbital cycle climatic varia- 


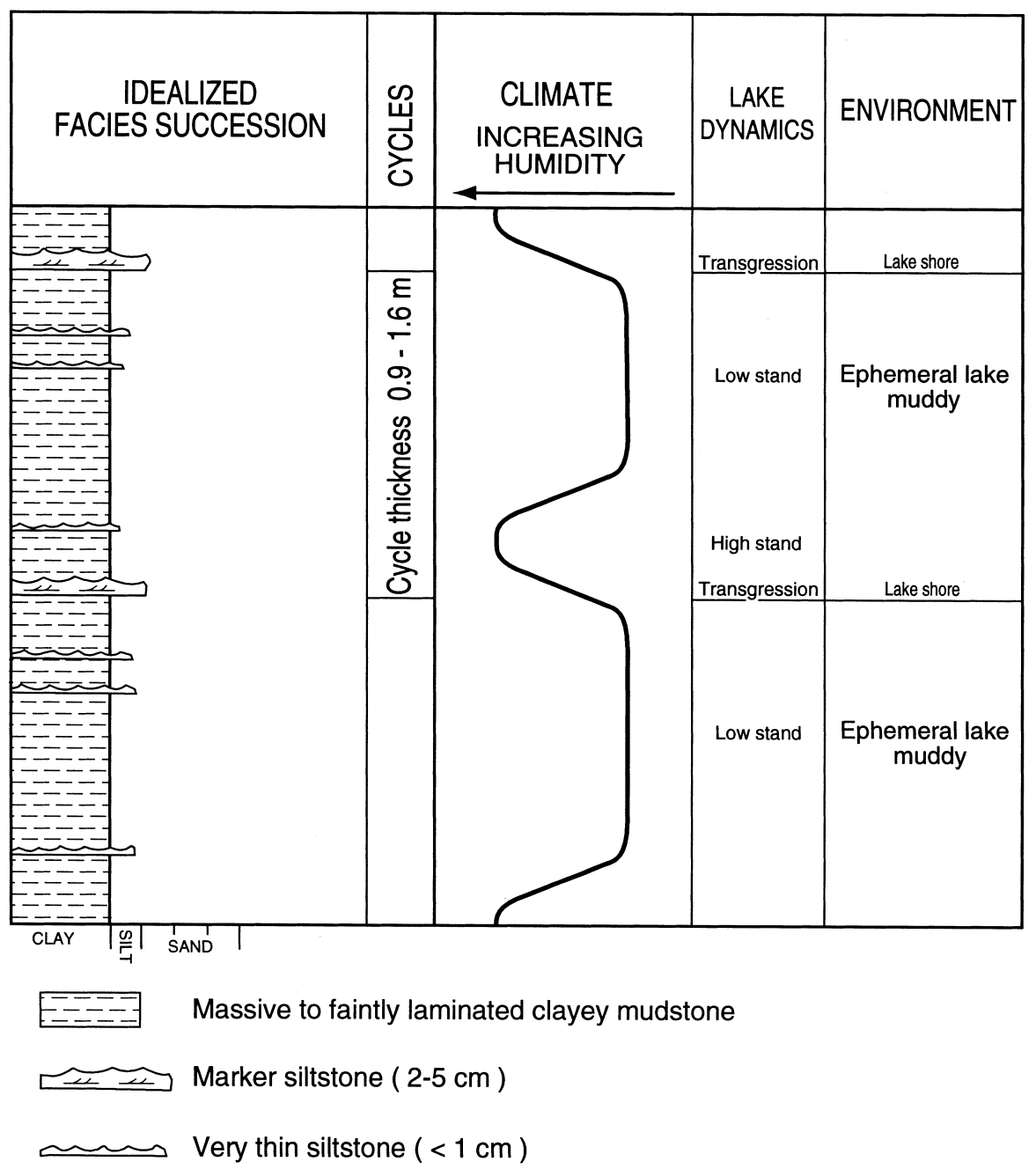

Fig. 12. Idealized facies successions and depositional cycles in the Carlsberg Fjord beds. The facies development is related to climatic changes (20 and $36 \mathrm{ka}$ cycles) and to lake dynamics. It should be noted, however, that short term (seasonal) changes in lake level probably was of higher amplitude than intermediate term orbitally controlled changes.

tion was significant. In the lower part of the unit the climate apparently varied between relatively humid and relatively dry; in the upper part of the unit climatic variation was less pronounced and dry phases no longer developed.

\section{Discussion}

The Late Triassic lake deposits of the Fleming Fjord Formation present a succession of 'climate-sensitive' sediments. Studies of facies and depositional cycles in the formation allow the reconstruction of seasonal, orbital and long-term climatic change and permit comparisons with conceptual (e.g. Robinson, 1973), as well as numerical climate models (Kutzbach and Gallimore, 1989; Kutzbach, 1994).

The lake deposits of the formation are arranged in four 'climate-sensitive' rock units, which coincide well with the lithostratigraphical units: the Edderfugledal Member, Malmros Klint Member, the Carlsberg Fjord beds and the Tait Bjerg Beds (Fig. 14). The lake deposits in the Fleming Fjord Formation are overlain by the perennial anoxic lake 


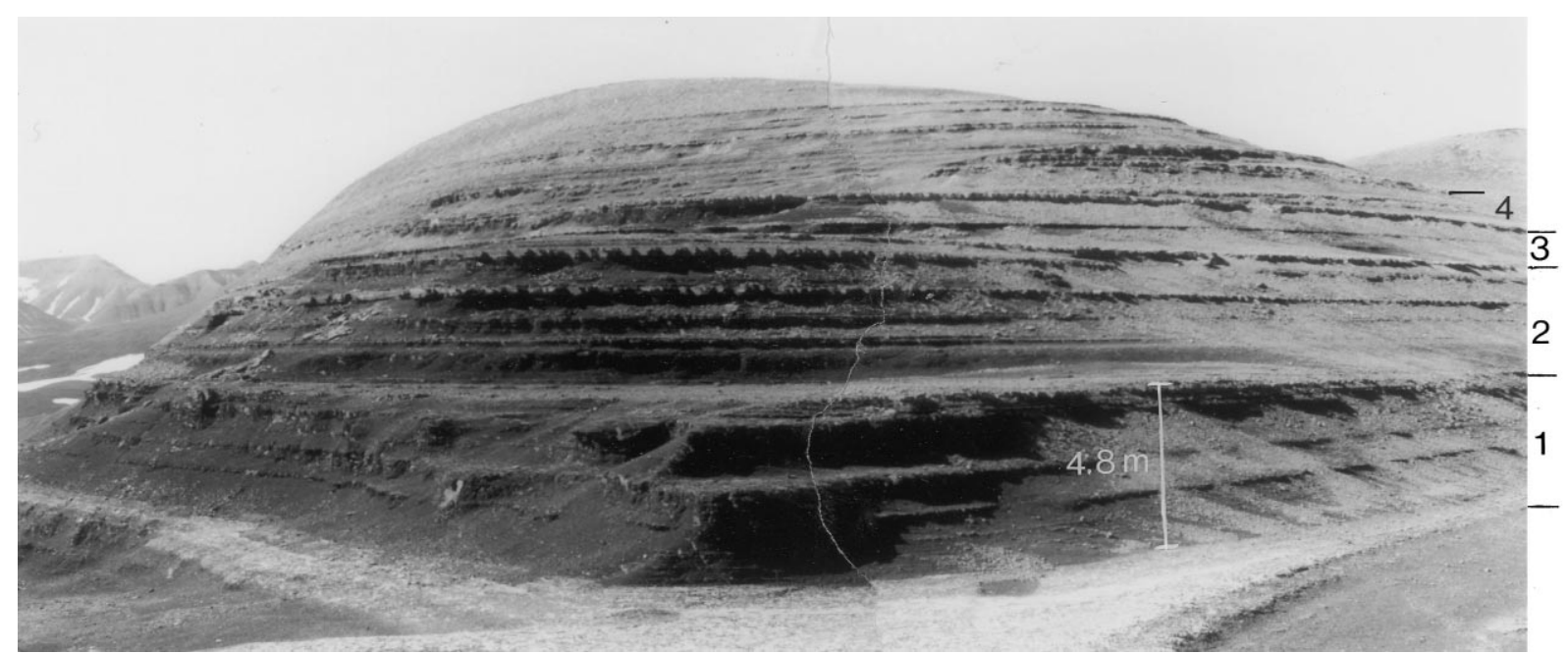

Fig. 13. Sedimentary cycles in the Tait Bjerg Beds, mountain ridge north of Macknight Bjerg (the 'Raceway'). Lowermost four major cycles in the Tait Bjerg Beds are numbered.

\begin{tabular}{|c|c|c|c|c|}
\hline & 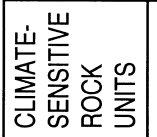 & LAKE ENVIRONMENT & CLIMATE & $\begin{array}{l}\text { SENSITIVITY TO } \\
\text { ORBITAL CHANGE }\end{array}$ \\
\hline 5 & & Deep, perennial lake & $\begin{array}{l}\text { Warm moist } \\
\text { temperate }\end{array}$ & Strong \\
\hline 4 & 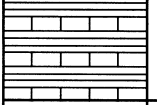 & $\begin{array}{l}\text { Shallow, perennial to } \\
\text { ephemeral lake }\end{array}$ & $\begin{array}{l}\text { Warm moist } \\
\text { temperate to steppe }\end{array}$ & Strong \\
\hline 3 & & Ephemeral lake & Dry, steppe & Weak \\
\hline 2 & 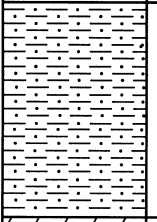 & Ephemeral lake & $\begin{array}{l}\text { Dry, steppe to } \\
\text { desert }\end{array}$ & Moderate \\
\hline 1 & 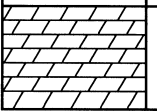 & Shallow lake & Dry, steppe & ? Strong \\
\hline
\end{tabular}

Fig. 14. Succession of 'climate-sensitive' rock units in the Late Triassic of the Jameson Land Basin, East Greenland. Evolution of lake system is related to a gradual change of climate belt. This long term (min. 5 m.y.) climatic trend can possibly be ascribed to a northward motion of the basin in the Late Triassic, and/or to a southward shift of climatic belts. $l=$ Edderfugledal Member; $2=$ Malmros Klint Member; 3 = Carlsberg Fjord beds (Ørsted Dal Member); 4 = Tait Bjerg Beds (Ørsted Dal Member); $5=$ Kap Stewart Formation.

mudstones and deltaic sandstones of the Kap Stewart Formation (Fig. 14; Dam and Surlyk, 1993).

Here we shall only discuss the upper three units in the Fleming Fjord Formation (units 2, 3, 4 in
Fig. 14). The three units all contain evidence of seasonal change in climate (precipitation) and lake environment. Those deductions are in agreement with conceptual models (e.g. Robinson, 1973) and model 


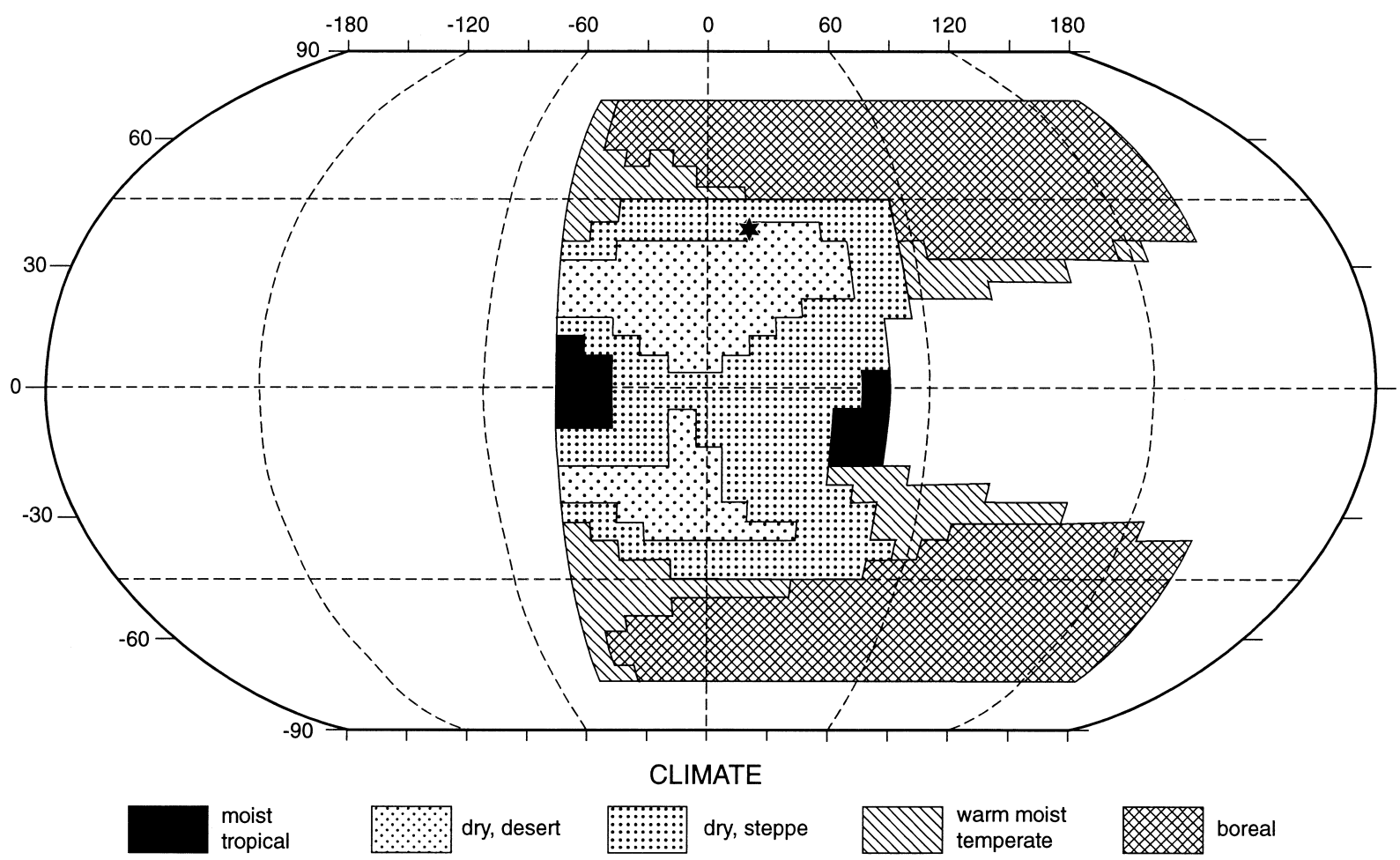

Fig. 15. Climatic belts (Köppen climate classes) on Pangaea (from Kutzbach, 1994). The portrayed pattern is for a situation with perihelion in January (southern summer). Note that the region of desert climate in the continental interior is smallest at the hemisphere with enhanced seasonality (southern continent). The approximate position of the Late Triassic Jameson Land Basin is indicated by a star. The position of the Jameson Land Basin in an area where dry desert-like, dry steppe-like and warm moist temperate climate belts meet, makes the basin sensitive to orbital controlled variations in precipitation.

experiments (e.g. Kutzbach, 1994). In the climate experiments large annual fluctuations in temperatures and soil moisture are indicated for large parts in the interior of Laurasia. Annual variations in precipitation are moderate during normal ('control') climate situations, but slightly larger during periods of enhanced seasonality.

The cyclicity of all three units is suggestive of orbital control on climate and lake sedimentation. These results are in agreement with climate model experiments of Kutzbach (1994). According to the experiments the climate of large parts of Laurasia were sensitive to orbital change. The size and character of climate change, however, was much dependent on the palaeoclimatic setting of the basin. Large parts of the dry interior of Laurasia experienced variations in annual precipitation of $\pm 25 \%$ in relation to orbital change. Related variations in soil moisture and runoff were also significant. Thus areas in the interior of Laurasia should shift from 'desert' to 'steppe' and back. Areas lying at the northern and western margins of the dry interior should shift from a dry steppe-like climate to a warm moist temperate climate and back (Fig. 15).

The sedimentary characteristics of the Malmros Klint cycles would seem to indicate lake and mud flat deposition in a climate that fluctuated between dry desert-like and dry steppe-like, the Carlsberg Fjord beds probably represent lake and mud flat deposition in a rather constant dry steppe-like climate, while the Tait Bjerg Beds record a climate that varied between dry steppe-like and warm moist temperate. The rich ichnofauna and the absence of evaporites suggest that the lakes had low salinities. This is a little surprising especially with regards to the Malmros Klint lakes which we infer were in the most dry climate belt. It is possible therefore that the basin received somewhat more precipitation than 
indicated in the climate models. The lacustrine succession of the Fleming Fjord Formation displays a systematic upward change in ichnotaxa (cf. Bromley and Asgaard, 1979). This trend is probably related to a gradual change in climate. Thus the succession of climate sensitive cycles in the Fleming Fjord Formation suggest an important long-term change in the overall climatic setting of the basin.

Comparisons with the map of Kutzbach (1994) indicate that such a climatic change could result from a northward Late Triassic plate drift of the Jameson Land Basin with time, from a southward shift of palaeoclimatic belts, or from a combination of both factors. Palaeomagnetic data indicate a northward drift of East Greenland of about $10^{\circ}$ in the Middle to Late Triassic (Kent and Clemmensen, 1996). Due to poor dating of the sampled interval in the MiddleLate Triassic Gipsdalen Formation the exact duration covered by the palaeopoles is uncertain (10-20 m.y.?). If the Fleming Fjord Formation represents ca. 5 m.y. of duration, the amount of latitudinal drift is expected to be a few degrees at best. For example, if the sampled section of the Fleming Fjord Formation (middle two/third of the formation, cf. Kent and Clemmensen, 1996) is equivalent in time to the Rutgers and Sommerset cored section in the Newark Basin (cf. Kent et al., 1995), the mean palaeomagnetic poles from these suggest only $\sim 1^{\circ}$ northward change in palaeolatitude for East Greenland.

Thus the amount of northward motion over Fleming Fjord time in East Greenland was probably small so that the observed upward change in climate indicators within the formation may be difficult to ascribe convincingly to plate drift, even though the overall pattern of facies change in the Gipsdalen, Fleming Fjord and Kap Stewart Formation lend themselves to this explanation (cf. Kent and Clemmensen, 1996). Southward shift of climatic belts probably in connection with a long-term drop in sea level is one alternative explanation for the evolution of facies within the Fleming Fjord Formation.

\section{Conclusions}

(1) The Upper Triassic Fleming Fjord Formation of East Greenland contains a 200-300 m thick, wellexposed lacustrine succession. The lake deposits formed in a partly fault-bounded basin in the central part of Laurasia at ca. $35^{\circ} \mathrm{N}$. The lake fluctuated much in size, but covered an area of about $3000 \mathrm{~km}^{2}$.

(2) The studied succession is composed of three well-defined lacustrine units. The sedimentary facies of the units record a systematic change in lake processes and environment with time. A siliciclastic (silt-rich), shallow to ephemeral lake (Malmros Klint Member) was followed by a siliciclastic (clay-rich) still shallow to ephemeral lake (Carlsberg Fjord beds) and finally by a mixed siliciclastic and carbonate, shallow but relatively perennial lake (Tait Bjerg Beds).

(3) The lake deposits possess evidence of climatic change of three different time scales. Seasonal change is suggested by densely spaced horizons with desiccation cracks, especially in the lowermost two units. Orbital change is suggested by the composite cyclicity in all three units. Best developed cycles are around $5 \mathrm{~m}$ thick and most likely represent the 100 ka eccentricity cycles, sedimentary cycles around 2 $\mathrm{m}$ (exact thickness varies between rock units) probably record obliquity cycles and sedimentary cycles close to $1 \mathrm{~m}$ are interpreted as the precession cycles. Long-term (ca. 5 m.y.) climatic change is recorded by the stacking of lacustrine units with different facies and cycles. The long-term trend is a change from deposition in an alternating dry desert-like and dry steppe-like climate to a relatively constant dry steppe-like climate and finally to an alternating dry steppe-like and warm moist temperate climate.

(4) The deductions of climate based on the sedimentary characteristics in the Fleming Fjord Formation agree well with recent climate model experiments. The frequent occurrence of aquatic trace fossils, however, suggest that precipitation (at least seasonally) was higher than indicated in the climate models.

(5) The long-term climatic trend deduced from the sedimentary succession is explained by a slow northward drift of the basin during the Late Triassic. Combined cyclostratigraphic and palaeomagnetic investigations indicate that the studied succession was deposited in ca. 5 m.y. In this time interval there was a northward drift of the basin of ca. 1 to 2 degrees. This contributed to change the overall climatic setting of the basin from a marginal desert climate belt to a marginal warm moist temperate climate belt in the northern hemisphere. 


\section{Acknowledgements}

We wish to thank F. Surlyk for his very constructive review, M. Vesterager for typing the manuscript and R. Madsen for making the illustrations. The field project was supported by the Carlsberg Foundation, the Division of Polar Programs of the National Science Foundation (USA), the Polar Earth Sciences and Geology and Stratigraphy Programs of the National Science Foundation (USA), and by the Putnam Expeditionary Fund of the Museum of Comparative Zoology (USA). We gratefully acknowledge the permission of the Commission for Scientific Research in Greenland to conduct field studies in Jameson Land.

\section{References}

Aigner, T., Bachmann, G.H., 1992. Sequence-stratigraphical framework of the German Triassic. Sediment. Geol. 80, 115135.

Alt, S., Arz, W., Gaupp, R., 1995. Time series analysis of lacustrine deposits based on Natural gamma-ray spectrometry and lamina thickness - the example of Devonian lakes, Orcadian Basin, Northern Scotland. First Int. Limno-geological Congr., Copenhagen, p. 6 (abstract).

Berger, A., Loutre, M.F., 1994. Astronomical forcing through geological time. In: De Boer, P.L., Smith, D.G. (Eds), Orbital Forcing and Cyclic Sequences. Int. Assoc. Sedimentol. Spec. Publ. 19, 15-24.

Bromley, R., Asgaard, U., 1979. Triassic Freshwater ichnocoenoses from Carlsberg Fjord, East Greenland. Palaeogeogr., Palaeoclimatol., Palaeoecol. 28, 39-80.

Clemmensen, L.B., 1978. Lacustrine facies and stromatolites from the Middle Triassic of East Greenland. J. Sediment. Petrol. 48, 1111-1128.

Clemmensen, L.B., 1979. Triassic lacustrine red-beds and palaeoclimate: The 'Buntsandstein' of Helgoland and the Malmros Klint Member of East Greenland. Geol. Rundsch. $68,748-774$.

Clemmensen, L.B., 1980a. Triassic rift sedimentation and palaeogeography of central East Greenland. Bull. Grønl. Geol. Unders. 136, $72 \mathrm{pp}$.

Clemmensen, L.B., 1980b. Triassic lithostratigraphy of East Greenland between Scoresby Sund and Kejser Franz Josephs Fjord. Bull. Grønl. Geol. Unders. 139, 56 pp.

Clemmensen, L.B., Kent, D.V., 1995. A Late Triassic lake system in East Greenland: sedimentary cycles and magnetostratigraphy. First Int. Limno-geological Congr., Copenhagen, pp. 22-23 (abstract).

Dam, G., Surlyk, F., 1993. Cyclic sedimentation in a large wave-and storm-dominated anoxic lake; Kap Stewart Forma- tion (Rhaetian-Sinemurian), Jameson Land, East Greenland. Int. Assoc. Sedimentol. Spec. Publ. 18, 419-448.

De Boer, P.L., Smith, D.G., 1994. Orbital forcing and cyclic sequences. In: De Boer, P.L., Smith, D.G. (Eds.), Orbital Forcing and Cyclic Sequences. Spec. Publ. Int. Assoc. Sedimentol. 19, $1-14$.

Defretin-Lefranc, S., 1969. III. Notes on Triassic stratigraphy and paleontology of north-eastern Jameson Land. Les conchostraces Triassiques du Groenland Oriental. Medd. Grønl. $168,123-136$.

Demico, R.V., Gierlowski-Kordesch, E., 1986. Facies sequences of a semi-arid closed basin: the Lower Jurassic East Berlin Formation of the Hartford Basin, New England, U.S.A. Sedimentology 33, 107-118.

Dubiel, R.F., Parrish, J.T., Parrish, J.M., Good, S.C., 1991. The Pangaean megamonsoon - evidence from the Upper Triassic Chinle Formation, Colorado Plateau. Palaios 6, 347-370.

Fischer, A.G., Roberts, L.T., 1991. Cyclicity in the Green River Formation (Lacustrine Eocene) of Wyoming. J. Sediment. Petrol. 61, 1146-1154.

Gierlowski-Kordesch, E., Rust, B.R., 1994. The Jurassic East Berlin Formation, Hartford Basin, Newark Supergroup (Conneticut and Massachussetts): a saline lake-playa-alluvial plain system. Sedimentology and geochemistry of modern and ancient saline lakes. SEPM Spec. Publ. 50, 249-265.

Grasmück, K., Trümpy, R., 1969. I. Notes on Triassic stratigraphy and paleontology of north-eastern Jameson Land. Triassic stratigraphy and general geology of the county around Fleming Fjord (East Greenland). Medd. Grønl. 168, 5-71.

Haq, B.U., Hardenbol, J., Vail, P.R., 1988. Mesozoic and Cenozoic chronostratigrpahy and cycles of sea-level changes. In: Wilgus, C.K., Hastings, C.A., Kendall, C.G.St.C., Posamentier, H.W., Ross, C.A., Van Wagoner, J.C. (Eds.), SEPM Spec. Publ. 42, 71-108.

Jenkins, F.A., Jr., Shubin, N.H., Amaral, W.W., Gatesy, S.M., Schaff, C.R., Clemmensen, L.B., Downs, W.R., Davidson, A.R., Bonde, N., Osbæck, F., 1994. Late Triassic continental vertebrates and depositional environments of the Fleming Fjord Formation, Jameson Land, East Greenland. Medd. Grønl. Geosci. 32, 25 pp.

Jenkins Jr., F.A., Gatesy, S.M., Shubin, N.H., Amaral, W.W., 1997. Haramiyids and Triassic mammalian evolution. Nature 385, 715-718.

Kent, D.V., Clemmensen, L.B., 1996. Paleomagnetism and cycle stratigraphy of the Triassic Fleming Fjord and Gipsdalen Formations of East Greenland. Bull. Geol. Soc. Den. 42, 121136.

Kent, D.V., Olsen, P.E., Witte, W.K., 1995. Late Triassicearliest Jurassic geomagnetic polarity sequence and paleolatitudes from drill cores in the Newark rift basin, eastern North America. J. Geophys. Res. 100, 14965-14998.

Koeppe, C.E., De Long, G.C., 1958. Weather and Climate. McGraw-Hill, 341 pp.

Kutzbach, J.E., 1994. Idealized Pangean climates: Sensitivity to orbital change. In: Klein, G.D. (Ed.), Paleoclimate, Tectonism, and Sedimentation during Accretion, Zenith, and Breakup of a Supercontinent. Geol. Soc. Am. Spec. Pap. 289, 41-55. 
Kutzbach, J.E., Gallimore, R.G., 1989. Pagaean climates: Megamonsoons of the megacontinent. J. Geophys. Res. 94, 33413357.

Olsen, P.E., 1986. A 40-million-year lake record of early Mesozoic climatic forcing. Science 234, 842-848.

Olsen, P.E., Kent, D.V., 1996. Milankovitch climate forcing in the tropics of Pangaea during the Late Triassic. Palaeogeogr., Palaeoclimatol., Palaeoecol. 122, 1-26.

Robinson, P.L., 1973. Palaeoclimatology and continental drift. In: Tarling, D.H., Runcorn, S.K. (Eds), Implications of Continental Drift to the Earth Sciences. Academic Press, London, pp. 451-476.

Rust, R.G., Nanson, G.C., 1989. Bedload transport of mud as pedogenic aggregates in modern and ancient rivers. Sedimentology 36, 291-306.

Rust, R.G., Nanson, G.C., 1991. Bedford transport of mud as pedogenic aggregates in modern and ancient rivers. Reply to discussion. Sedimentology 38, 157-160.

Smooth, J.P., 1991. Sedimentary facies and depositional environments of early Mesozoic Newark Supergroup basins, eastern North America. Palaeogeogr., Palaeoclimatol., Palaeoecol. 84, 369-423.

Smooth, J.P., Olsen, P.E., 1988. Massive mudstones in basin analysis and paleoclimatic interpretation of the Newark Supergroup. In: Manspeizer, W. (Ed.), Triassic-Jurassic Rifting. Continental Breakup and the Origin of the Atlantic Ocean and Passive Margins. Part A. Dev. Geotecton. 22, 249-274.

Surlyk, F., 1990. Timing, style and sedimentary evolution Late Paleozoic-Mesozoic extensional basins of East Greenland. In: Hardman, R.F.P., Brooks, J. (Eds), Tectonic Events Responsible for Britain's Oil and Gas Reservoirs. Geol. Soc. London Spec. Publ. 55, 107-125.
Surlyk, F., Clemmensen, L.B., Larsen, H.C., 1981. Post-Palaeozoic evolution of the East Greenland continental margin. In: Kerr, J.W., Ferguson, A.J. (Eds), Geology of the North Atlantic Borderlands. Can. Soc. Pet. Geol. Mem. 7, 611-645.

Surlyk, F., Hurst, J.M., Piasecki, S., Rolle, F., Scholle, P.A., Stemmerik, L., Thomsen, E., 1986. The Permian of the western margin of the Greenland Sea - a future exploration target. In: Halbouty, M.T. (Ed.), Future Petroleum Provinces of the World. Am. Assoc. Pet. Geol. Mem. 40, 629-652.

Talbot, M.R., Holm, K., Williams, M.A.J., 1994. Sedimentation in low-gradient desert margin systems: A comparison of the Late Triassic of northwest Sommerset (England) and the Late Quaternary of east-central Australia. In: Rosen, M.R. (Ed.), Palaeoclimate and Basin Evolution of Playa Systems. Geol. Soc. Am. Spec. Pap. 289, 97-117.

Tucker, M.E., 1978. Triassic lacustrine sediments from South Wales: Shore-zone clastics, evaporites and carbonates. In: Matter, A., Tucker, M.E. (Eds), Modern and Ancient Lake Sediments. Int. Assoc. Sedimentol. Spec. Publ. 2, 205-224.

Van Houten, F.B., 1964. Cyclic lacustrine sedimentation, Upper Triassic Lockatong Formation, central New Jersey and adjacent Pennsylvania. In: Mermaid, O.F. (Ed.), Symposium on Cyclic Sedimentation. Kans. Geol. Surv. Bull. 169, 497-531.

Wright, V.P., Platt, N.H., 1995. Seasonal wetland carbonate sequences and dynamic catenas: a re-appraisal of palustrine limestones. Sediment. Geol. 99, 65-71.

Yang, C.S., Baumfalk, Y.A., 1994. Milankovitch cyclicity in the Upper Rotliegend Group of the Netherlands offshore. Spec. Publ. Int. Assoc. Sedimentol. 19, 47-61.

Zwan, C.J., Spaak, P., 1992. Lower to Middle Triassic sequence stratigraphy and climatology of the Netherlands, a model. Palaeogeogr., Palaeoclimatol., Palaeoecol. 91, 277-290. 